\title{
Simulating the role of gravel on the dynamics of permafrost on the Qinghai-Tibetan Plateau
}

\author{
S. $\mathrm{Yi}^{1}$, J. Chen ${ }^{1}, \mathrm{Q} \cdot \mathrm{Wu}^{2}$, and Y. Ding ${ }^{1}$
}

${ }^{1}$ State Key Laboratory of Cryospheric Sciences, Cold and Arid Regions Environmental and Engineering Research Institute, Chinese Academy of Sciences, 320 Donggang West Road, 730000, Lanzhou, Gansu, China

${ }^{2}$ State Key Laboratory of Frozen Soil Engineering, Cold and Arid Regions Environmental and Engineering Research Institute, Chinese Academy of Sciences, 320 Donggang West Road, 730000, Lanzhou, Gansu, China

Received: 3 September 2013 - Accepted: 9 September 2013 - Published: 24 September 2013 Correspondence to: S. Yi (yis@Izb.ac.cn)

Published by Copernicus Publications on behalf of the European Geosciences Union.

Simulating the role of

gravel on the

dynamics of

permafrost

S. Yi et al.

Title Page

Abstract

Conclusions

Tables

14

4

Back

\section{Introduction}

References

Figures

DI

Close

Full Screen / Esc

Printer-friendly Version

Interactive Discussion 


\section{Abstract}

Gravel (particle size $\geq 2 \mathrm{~mm}$ ) is common in soil profiles of the Qinghai-Tibetan Plateau (QTP). It has different thermal and hydrological properties than other fine mineral soils (particle size $<2 \mathrm{~mm}$ ), which may have significant impacts on the thermal and hydro-

5 logical processes of soil. However, few models have considered gravel. In this study, we implemented the thermal and hydraulic properties of gravel into the Dynamic Organic Soil-Terrestrial Ecosystem Model to develop new schemes to simulate the dynamics of permafrost on the QTP. Results showed that: (1) the widely used Farouki thermal scheme always simulated higher thermal conductivity of frozen soils than unfrozen soils with the same soil water content; therefore it tends to overestimate permafrost thickness strongly; (2) there exists a soil moisture threshold, below which the new set of schemes with gravel simulated smaller thermal conductivity of frozen soils than unfrozen soils; (3) soil with gravel has higher hydraulic conductivity and poorer water retention capability; and simulations with gravel were usually drier than those without gravel; and (4) the new schemes simulated faster upward degradation than downward degradation; and the simulated permafrost thicknesses were sensitive to the fraction of gravel, the gravel size, the thickness of soil with gravel, and the subsurface drainage. To reduce the uncertainties in the projection of permafrost degradation on the QTP, more effort should be made to: (1) developing robust relationships between soil ther(2) compiling spatial datasets of the vertical distribution of gravel content based on measurements during drilling or the digging of soil pits.

\section{Introduction}

Permafrost, the frozen soil or rock that has existed for the past 24 consecutive months, occupies about half of the total area of the Qinghai-Tibetan Plateau (QTP). Over the last few decades, especially since late 1980s, permafrost has degraded substantially
Simulating the role of gravel on the dynamics of permafrost

S. Yi et al.

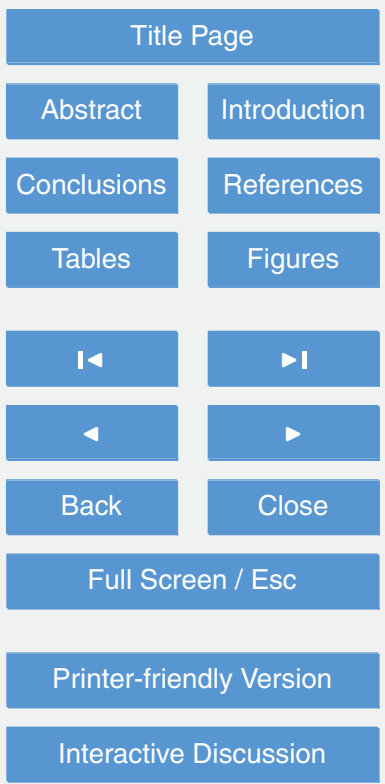


on the QTP (Jin et al., 2011). The thickness of active layer, the annually freezing and thawing part above permafrost, has increased at a rate of $\sim 7.5 \mathrm{~cm} \mathrm{yr}^{-1}$ from 1995 to 2007 along the Qinghai-Tibetan Highway (Wu and Zhang, 2010), and the mean annual soil temperature at $6 \mathrm{~m}$ in permafrost has increased $\sim 0.47^{\circ} \mathrm{C}$ from 1995 to 52005 (Wu and Zhang, 2008). Degradation of permafrost has potentially strong impacts on hydrology (Ye et al., 2009), ecosystem dynamics (Yi et al., 2011), and infrastructure (Wu et al., 2004). Therefore, accurately simulating the dynamics of the active layer and permafrost on the QTP is vital for developing policies to both lessen the impacts of change and to adapt to change.

10 Some modeling studies have used specified constant soil thermal properties to simulate active layer dynamics at site scale (Qin et al., 2013) and at plateau scale (Nan et al., 2005; Zhuang et al., 2010; Pang et al., 2012). These thermal properties include thermal conductivities and heat capacities for both frozen and unfrozen soils, which are derived from borehole temperature measurements on the QTP (Nan et al., 2005). How15 ever, these properties are not constant when soil hydrological regimes are changed. Other modeling studies simulated the effects of soil water content on soil thermal and hydraulic properties (Tan et al., 2010; Guo et al., 2012, 2013). However, these properties have been calculated based only on soil textures with grain size diameter less than $2 \mathrm{~mm}$ (Oleson et al., 2010), and without considering gravel content (diameter $>2 \mathrm{~mm}$ ).

Gravel is common in soil profiles on the QTP due to weak chemical and biological weathering (Arocena et al., 2012). For example, mass fractions of gravel content account for $45 \%$ and $48 \%$ of the top $20 \mathrm{~cm}$ in alpine steppe soil (858 profiles) and alpine meadow soil (657 profiles), respectively (Fan et al., 2006); and about 5-45\% of the $1.5 \mathrm{~m}$ soil profiles of the western QTP (Wu et al., 2011). Gravel also exists in deeper soils based on reports of borehole drilling activity, although no quantitative descriptions are available (Nan et al., 2005). Gravel has distinctly different thermal and hydraulic properties than finer grained soils. However, none of the current land surface models, ecosystem models or permafrost models has considered the effects of gravel, with the exception of the NEST model which decreased porosity with increasing gravel content

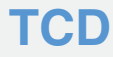

$7,4703-4740,2013$

Simulating the role of gravel on the dynamics of permafrost

S. Yi et al.

Title Page

Abstract Introduction

Conclusions

Tables

References

Figures

14

$>$ I

4

Back

$\checkmark$

Close

Printer-friendly Version

Interactive Discussion 
(Zhang et al., 2013); and GEOtop model which set gravel as a soil type (soil thermal and hydraulic properties do not vary with gravel content; Gubler et al., 2013). The role of gravel on the soil thermal and hydrological processes is incompletely understood, as is its role in the changing dynamics of permafrost on the QTP.

5 Because of the ubiquitous existence of gravel on the QTP and its inadequate representation in models, in this study our objectives were to: (1) develop a suite of schemes to account for the effects of gravel on soil thermal and hydraulic properties; (2) compare the performance of the new set of schemes with the widely used schemes without gravel in an ecosystem model using measurements from a site with permafrost on the 10 QTP; and (3) test the sensitivity of active layer and permafrost dynamics to changes in gravel fraction, size, and soil texture configuration at the same site.

\section{Methodology}

\subsection{Model descriptions}

In this study, we used a dynamic organic soil version of Terrestrial Ecosystem Model 15 (DOS-TEM) to simulate soil thermal and hydrological processes on the QTP. The DOSTEM was originally designed to simulate the effects of wildfire on soil organic layers and permafrost dynamics (Yi et al., 2009a, 2010; Yuan et al., 2012). The DOS-TEM consists of four modules including environmental, ecological, fire disturbance and dynamic organic soil modules. The environmental module operates at a daily time step using daily air temperature, surface solar radiation, and precipitation and vapor pressure datasets, which are downscaled from monthly input data (Yi et al., 2009a). The DOS-TEM was verified against analytical solutions on soil temperature and freezing/thawing fronts (Yi et al., 2013a); and validated against soil temperature measurements at site scale in Alaska (Yi et al., 2009a), the QTP (Yi et al., 2013b) and Siberia (Yi et al., 2013a).

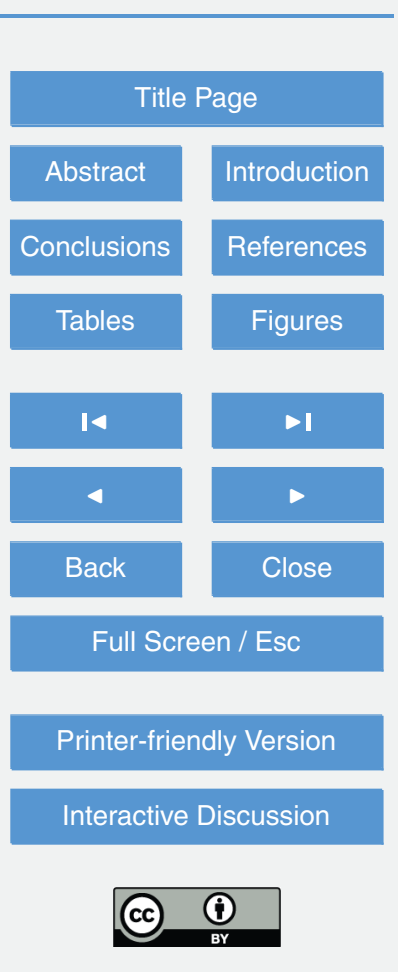

\section{Simulating the role of gravel on the dynamics of permafrost \\ S. Yi et al.}


soil and the underlying aquifer, based on Community Land Model version 4 (CLM4; Oleson et al., 2010). Due to heterogeneous thawing rate and slope, runoff from perched saturated zone above permafrost table is common (Wright et al., 2009). Neglection of this process in modeling studies will cause overestimation of soil moisture (Swenson 5 et al., 2012). Therefore, we also implemented runoff from the perched saturated zone above permafrost table following Swenson et al. (2012),

$Q_{\text {perched }}=\alpha K_{\mathrm{p}}\left(z_{\text {frost }}-z_{\text {perched }}\right) \sin \left(\frac{\pi}{180} \theta\right)$

where $\alpha$ is an adjustable parameter $\left(0.6 \mathrm{~m}^{-1}\right), K_{\mathrm{p}}$ is the mean saturated hydraulic conductivity within perched saturated zone $\left(\mathrm{mm} \mathrm{s}^{-1}\right) ; z_{\text {frost }}$ and $z_{\text {perched }}$ are the depths to 10 permafrost table and perched water table $(\mathrm{m})$, respectively; and $\theta$ is grid mean slope $\left({ }^{\circ}\right)$.

We assumed $4.1 \mathrm{~m}$ soil above $56 \mathrm{~m}$ beckrock, which is similar to that of Guo and Wang (2013). Soil surface temperature and heat flux at the bottom of the soil profile were used as the boundary conditions for solving finite difference equations. In the 15 first versions of the DOS-TEM, soil surface temperature was calculated using air temperature only. In a recent version, Yi et al. (2013b) developed a new set of empirical equations for applications on the QTP:

$T_{\mathrm{s}, \max }=0.79 T_{\mathrm{a}, \max }+0.05 e^{-0.5 \mathrm{LAI}} R+68.74$

$T_{\mathrm{s}, \min }=0.86 T_{\mathrm{a}, \min }+0.65 \mathrm{LAl}+38.37$

$T_{\mathrm{s}}=0.47 T_{\mathrm{s}, \max }+0.56 T_{\mathrm{s}, \min }-14.15$
TCD

7, 4703-4740, 2013

Simulating the role of gravel on the dynamics of permafrost

S. Yi et al.

Title Page

Abstract Introduction

Conclusions References

Tables Figures

14 $>1$

4

Back

Close

Full Screen / Esc

Printer-friendly Version

Interactive Discussion 
where $T_{\mathrm{s}, \max }, T_{\mathrm{s}, \min }$, and $T_{\mathrm{s}}$ are daily maximum, minimum and mean soil surface temperature $(\mathrm{K})$, respectively; $T_{\mathrm{a} \text {,max }}$ and $T_{\mathrm{a} \text {,min }}$ are daily maximum and minimum air temperature $(K)$ respectively; LAl is leaf area index $\left(\mathrm{m}^{2} \mathrm{~m}^{-2}\right)$ and $R$ is daily mean downward solar radiation $\left(\mathrm{W} \mathrm{m}^{-2}\right)$.

\subsection{Effects of gravel on soil properties}

Soil is a mixture of porous organic material and a distribution of mineral grain sizes. Soil texture classifications do not consider gravel and models usually neglect gravel. The presence of gravel affects pore space and thermal and hydraulic properties of soil.

\section{Soil Porosity}

10 The presence of gravel can have different effects on porosity that depend on the nature of the mixture (Zhang et al., 2011):

$\phi_{\mathrm{m}}=\left\{\begin{array}{l}\left(f_{\mathrm{g}}-\sigma f_{\mathrm{g}}+\sigma\right) \phi_{\mathrm{g}}+f_{\mathrm{f}} \phi_{\mathrm{f}}-\sigma f_{\mathrm{g}} \quad f_{\mathrm{f}}<\phi_{\mathrm{g}} \\ (1-\sigma) f_{\mathrm{g}} \phi_{\mathrm{g}}+f_{\mathrm{f}} \phi_{\mathrm{f}} \quad f_{\mathrm{f}} \geq \phi_{\mathrm{g}}\end{array}\right.$

where $\sigma$ is degree of mixture, with 0 means no mixture and 1 ideal-packing. $\phi_{\mathrm{m}}, \phi_{\mathrm{f}}$, and $\phi_{\mathrm{g}}$ are porosity of mixed soil, fine soil, and gravel, respectively. $f_{\mathrm{f}}$ and $f_{\mathrm{g}}$ are the volumetric fraction of fine mineral and gravel, the sum of which equals $1 . \phi_{\mathrm{f}}$ can be quantified based on fine soil texture (Oleson et al., 2010). $\sigma$ can be calculated as:

$\sigma=0.0363 \frac{d_{\mathrm{g}}}{d_{\mathrm{f}}}+0.2326$

where $d_{\mathrm{g}}$ and $d_{\mathrm{f}}$ are the mean particle diameters (assuming spherical shape) of the gravel and fine mineral components, respectively. $\phi_{\mathrm{g}}$ is mainly affected by median grain size $\left(D_{50}, \mathrm{~m}\right)$ (Frings et al., 2011), in this study, we used the empirical equation of Wu

Simulating the role of gravel on the dynamics of permafrost

S. Yi et al.

Title Page

Abstract Introduction

Conclusions

Tables

References

Figures

14

$\Delta$ I

4

Back

Close

Full Screen / Esc

Printer-friendly Version

Interactive Discussion 
and Wang (2006), and assumed that $D_{50}=d_{\mathrm{g}}$ in the following equation:

$\phi_{\mathrm{g}}=0.13+\frac{0.21}{\left(1000 D_{50}+0.002\right)^{0.21}}$

\section{Soil thermal conductivity}

Soil thermal conductivity is affected by composition of organic material and mineral soil 5 particles, water content and thermal state (frozen or unfrozen). Soil thermal conductivity is usually calculated as a function of thermal conductivity of soil solid, thermal conductivity of dry soil, thermal conductivity of saturated soil, and Kersten Number (sensitivity of thermal conductivity to changes of water content). Different methods of calculating the above variables result in different schemes. For thermal conductivity of solid $\left(\lambda_{s}\right)$, the Farouki scheme calculated $\lambda_{s}$ based on volumetric fractions of sand and clay of soil, while Johansen (1975) used:

$\lambda_{\mathrm{s}}=\lambda_{\mathrm{q}}^{f_{\mathrm{q}}} \lambda_{\mathrm{o}}^{f_{\mathrm{o}}}$

where $\lambda_{\mathrm{q}}$ and $\lambda_{\mathrm{o}}$ are thermal conductivities of quartz $\left(7.69 \mathrm{~W} \mathrm{~m}^{-1} \mathrm{~K}^{-1}\right)$ and other material $\left(2 \mathrm{~W} \mathrm{~m}^{-1} \mathrm{~K}^{-1}\right)$, respectively. $f_{\mathrm{q}}$ and $f_{\mathrm{o}}$ are volumetric fraction of quartz and other material, respectively.

Chen et al. (2012) further considered the thermal conductivity of organic material $\left(0.25 \mathrm{~W} \mathrm{~m}^{-1} \mathrm{~K}^{-1}\right)$ into the equation of Johansen. Côté and Konrad (2005) also used the geometric mean method of Johansen, but considered lots of mineral types which are difficult to prescribe in practice. Therefore, under the circumstance of difficulty of getting detailed organic and mineral content information, we followed Luo et al. (2009) to calculate the thermal conductivity of soil without gravel using the Johansen scheme.

For dry soil thermal conductivity $\left(\lambda_{\text {dry }}\right)$, both Farouki and Johansen schemes calculated $\lambda_{\text {dry }}$ using soil bulk density and did not consider gravel. Côté and Konrad (2005)

Simulating the role of gravel on the dynamics of permafrost

S. Yi et al.

Title Page

Abstract Introduction

Conclusions

Tables

References

Figures

14

$>1$

4

Back

Close

Full Screen / Esc

Printer-friendly Version

Interactive Discussion 
calculated $\lambda_{\text {dry }}$ as:

$\lambda_{\mathrm{dry}}=\chi 10^{-\eta \phi_{\mathrm{m}}}$

where $\chi\left(\mathrm{W} \mathrm{m}^{-1} \mathrm{~K}^{-1}\right)$ and $\eta$ (no unit) are parameters accounting for the particle shape effect. Côté and Konrad (2005) provided $\chi$ and $\eta$ values for gravel, and for fine mineral

and organic materials. For gravel-fine mineral mixed soil, we used

$\lambda_{\text {dry,m }}=\lambda_{\text {dry,g }} f_{g}+\lambda_{\text {dry,f }} f_{f}$

where $\lambda_{\mathrm{dry}, \mathrm{m}}, \lambda_{\mathrm{dry}, \mathrm{g}}$ and $\lambda_{\mathrm{dry}, \mathrm{f}}$ are dry thermal conductivities of mixed soilgravel soil, and finer mineral soils, respectively.

For saturated soil thermal conductivity $\left(\lambda_{\text {sat }}\right)$, the Farouki, Johansen schemes and

Côté and Konrad (2005) all used the following equation:

$\lambda_{\text {sat }}=\left\{\begin{array}{l}\lambda_{\mathrm{s}}^{1-\phi_{\mathrm{m}}} \lambda_{\text {liq }}^{\phi_{\mathrm{m}}} T \geq T_{\mathrm{f}} \\ \lambda_{\mathrm{s}}^{1-\phi_{\mathrm{m}}} \lambda_{\text {liq }}^{\phi_{u}} \lambda_{\text {ice }}^{\phi_{\mathrm{m}}-\phi_{u}} T<T_{\mathrm{f}}\end{array}\right.$

where $\lambda_{\text {liq }}$ and $\lambda_{\text {ice }}$ are thermal conductivities of water $\left(0.6 \mathrm{~W} \mathrm{~m}^{-1} \mathrm{~K}^{-1}\right)$ and ice $\left(2.29 \mathrm{~W} \mathrm{~m}^{-1} \mathrm{~K}^{-1}\right)$, respectively. $T$ and $T_{\mathrm{f}}$ are soil temperature and soil freezing temperature, respectively.

For the Kersten number (Ke), only Côté and Konrad (2005) considered coarse materials:

$K_{\mathrm{e}}=\frac{\kappa S}{1+(\kappa-1) S}$

where $S$ is degree of soil saturation, and $k$ is empirical parameter used to account for different soil types. Values have been assigned for both frozen and unfrozen states

Simulating the role of

gravel on the

dynamics of

permafrost

S. Yi et al.

Title Page

Abstract

Introduction

Conclusions

References

Tables

Figures

14

$>1$

4

Back

Close

Full Screen / Esc

Printer-friendly Version

Interactive Discussion 
and for coarse material, fine mineral, and organic in Côté and Konrad (2005). For mixed soil:

$K_{\mathrm{e}, \mathrm{m}}=K_{\mathrm{e}, \mathrm{g}} f_{\mathrm{g}}+K_{\mathrm{e}, \mathrm{f}} f_{\mathrm{f}}$

where $K_{\mathrm{e}, \mathrm{m}}, K_{\mathrm{e}, \mathrm{g}}$ and $K_{\mathrm{e}, \mathrm{f}}$ are Kersten numbers of mixed gravel-fine mineral soil, gravel 5 and fine mineral soils, respectively.

Finally, soil thermal conductivity $\left(\lambda_{\mathrm{m}}\right)$ for gravel-fine mineral mixed soil was then calculated as

$\lambda_{\mathrm{m}}=\left\{\begin{array}{l}K_{\mathrm{e}, \mathrm{m}} \lambda_{\mathrm{sat}}+\left(1-K_{\mathrm{e}, \mathrm{m}}\right) \lambda_{\mathrm{dry}, \mathrm{m}} S>10^{-5} \\ \lambda_{\mathrm{dry}, \mathrm{m}} S \leq 10^{-5}\end{array}\right.$

\section{Pore size distribution parameter}

10 The pore size distribution parameter $(B)$ is an important parameter in calculating both soil hydraulic conductivity and matric potential (Clapp and Hornberger, 1978; Cosby et al. 1984). For fine mineral soils, $B$ is related to clay content, for example, values of clay soil and sand soil are 12.13 and 3.39, respectively. With a larger $B$ value, hydraulic conductivity decreases and the absolute value of matric potential increases more rapid with the same amount of decrease of soil moisture. We couldn't find any explicit values of $B$ for gravel from our search of the literature. Because gravel has low capacity to hold water (Stephens et al., 1998), we set $B$ of gravel to be 1 ( $B$ of sand and clay are about 3 and 12 , respectively). For soil with mixed gravel and finer grained mineral materials,

$B_{\mathrm{m}}=B_{\mathrm{g}} f_{\mathrm{g}}+B_{\mathrm{f}} f_{\mathrm{f}}$

where $B_{\mathrm{g}}$ and $B_{\mathrm{f}}$ are $B$ values for gravel and fine mineral, respectively.

Printer-friendly Version

Interactive Discussion

Simulating the role of

gravel on the

dynamics of

permafrost

S. Yi et al.

Title Page

Abstract

Introduction

Conclusions

Tables

References

Figures

14

$>$ I

4

Back

Close

Full Screen / Esc 


\section{Saturated matric potential}

Saturated matric potential $\left(\Psi_{\text {sat,f }}\right)$ for fine mineral is related to sand content, for example, absolute values of clay and sand are 390 and $47 \mathrm{~mm}$, respectively. We set saturated matric potential of gravel $\left(\Psi_{\text {sat,g }}\right)$ to be $0.1 \mathrm{~mm}$ so that the capability of gravel

5 holding water is very weak when it is saturated. For soil with mixed gravel and finer grained mineral materials,

$\Psi_{\text {sat }, \mathrm{m}}=\Psi_{\text {sat,g }}^{f_{\mathrm{g}}} \times A \Psi_{\text {sat, } \mathrm{f}}^{f_{\mathrm{f}}}$

\section{Saturated hydraulic conductivity}

Saturated hydraulic conductivity $\left(\mathrm{K}_{\mathrm{sat}, \mathrm{f}}\right)$ for fine mineral is related to sand content, for 10 example, values of clay and sand are 0.002 and $0.0236 \mathrm{~mm} \mathrm{~s}^{-1}$ in CLM4, respectively. For soil with mixed gravel and fine mineral,

$K_{\mathrm{sat}, \mathrm{m}}=\frac{g}{v}\left[\frac{d_{\mathrm{m}}^{2} \phi_{\mathrm{m}}^{3}}{180\left(1-\phi_{\mathrm{m}}\right)^{2}}\right]$

where $g$ is gravitational acceleration $\left(\mathrm{m} \mathrm{s}^{-2}\right), v$ is kinetic viscosity $\left(\mathrm{m}^{2} \mathrm{~s}^{-1}\right), \mathrm{d}_{\mathrm{m}}$ is the representative grain diameter of mixture, which is calculated based on representative grain diameters of gravel $\left(d_{\mathrm{g}}\right)$ and fine minerals $\left(d_{\mathrm{f}}\right)$ (Zhang et al., 2011).

The matric potential $\left(\psi_{\mathrm{m}}\right)$ and hydraulic conductivity $\left(K_{\mathrm{m}}\right)$ of mixture are then calculated as:

$\psi_{\mathrm{m}}=\psi_{\text {sat }, \mathrm{m}}\left(\frac{\theta_{\text {liq }}}{\phi_{\mathrm{m}}}\right)^{-B_{\mathrm{m}}}$

${ }_{20} K_{\mathrm{m}}=K_{\text {sat }, \mathrm{m}}\left(\frac{\theta_{\text {liq }}}{\phi_{\mathrm{m}}}\right)^{2 B_{\mathrm{m}}+3}$

Simulating the role of

gravel on the

dynamics of

permafrost

S. Yi et al.

Title Page

Abstract

Conclusions

Tables

I4

4

Back
Introduction

References

Figures

$\Delta$

$>$

Close

Full Screen / Esc

Printer-friendly Version

Interactive Discussion 
where $\theta_{\text {liq }}$ is volumetric water content of soil $\left(\mathrm{m}^{3} \mathrm{~m}^{-3}\right)$.

\section{Volumetric fraction of gravel}

Above descriptions used volumetric fractions of gravel and fine mineral soils. Field and laboratory work usually provide mass fractions. Therefore, we use the following to

5 calculate volumetric fraction of gravel $\left(f_{\mathrm{g}}\right)$ :

$f_{\mathrm{g}}=\frac{\phi_{\mathrm{f}} f_{\mathrm{g}, \mathrm{m}}}{\phi_{\mathrm{g}}\left(1-f_{\mathrm{g}, \mathrm{m}}\right)+\phi_{\mathrm{f}} f_{\mathrm{g}, \mathrm{m}}}$

where $f_{\mathrm{g}, \mathrm{m}}$ is the mass fraction of gravel.

\subsection{Site description}

The site tested in this study is near Beiluhe permafrost station $\left(34^{\circ} 49^{\prime} 46.2^{\prime \prime} \mathrm{N}\right.$,

$92^{\circ} 55^{\prime} 56.58^{\prime \prime} \mathrm{E}, 4,628 \mathrm{~m}$ a.s.I.), which is located in the ice-rich permafrost regions on the QTP (Fig. 1). Meteorological variables, including air temperature, radiation, precipitation, and humidity, and soil temperature and moisture (down to $1.6 \mathrm{~m}$ ) have been measured since 2002. Based on measurements, mean annual air temperature is $-3.6{ }^{\circ} \mathrm{C}$; mean annual downward solar radiation is $206.3 \mathrm{~W} \mathrm{~m}^{-2}$; and mean annual precipitation is $366 \mathrm{~mm} \mathrm{yr}^{-1}$ (Fig. 2). A borehole was drilled in 2002, and temperature sensors were installed down to $60 \mathrm{~m}$. Active layer thickness is about $3.4 \mathrm{~m}$; the lower boundary of permafrost is at a depth of about $20 \mathrm{~m}$ below soil surface (Fig. 3). Based on borehole measurements at 60 and $50 \mathrm{~m}$, the temperature gradient over the period of measurement is about $0.06^{\circ} \mathrm{C} \mathrm{m}^{-1}$.

20 Vegetation of the site is sparse. We specified leaf area index of this site to be $0.1 \mathrm{~m}^{2} \mathrm{~m}^{-2}$ in both April and October; and $0.6 \mathrm{~m}^{2} \mathrm{~m}^{-2}$ in July and August. Leaf area indices were set to be 0 in winter; and interpolated linearly between minimum and

Simulating the role of

gravel on the

dynamics of

permafrost

S. Yi et al.

Title Page

Abstract

Conclusions

Tables

14

4

Back
Introduction

References

Figures

$\rightarrow 1$

Close

Full Screen / Esc

Printer-friendly Version

Interactive Discussion 
maximum for the other months. The soil profile of Beiluhe region consists of $0.5-2.1 \mathrm{~m}$ sand with gravel on top of $<8 \mathrm{~m}$ silty clay (Lin et al., 2011). We specified the volumetric fraction of gravel content based on measurements from 4 pits of the same region (Yang et al., 2009), i.e. $40 \%$ in $0-5 \mathrm{~cm}$, and $50 \%$ in deeper soil layers. All soil layers were 5 assumed to be saturated and $-1{ }^{\circ} \mathrm{C}$ for initial conditions. For all the simulations at this site, DOS-TEM was first run with atmospheric driving variables of 2003 for $100 \mathrm{yr}$.

\subsection{Comparisons of different schemes}

We compared three sets of schemes (Table 1). The first set used schemes for soil thermal and hydraulic properties following the Community Land Model 4 (CLM4; Oleson et al., 2010). The second set was similar to the first set, with the exception of using a different thermal conductivity scheme. The third set considered the effects of gravel, which were described in Sect. 2.2. These sets of schemes are referred to as the CLM, CKJ, and CKJ-G hereafter. For each set of schemes, we run the DOS-TEM with different combinations of 3 different soil profiles: (1) $0.5 \mathrm{~m}$ sand (with and without gravel) on top of $3.6 \mathrm{~m}$ silty clay; (2) $1.3 \mathrm{~m}$ sand (with and without gravel) on top of $2.8 \mathrm{~m}$ silty clay; and (3) $2.1 \mathrm{~m}$ sand (with and without gravel) on top of $2 \mathrm{~m}$ silty clay; and 3 different slopes $\left(0,5\right.$ and $\left.10^{\circ}\right)$. For all simulations, the top $15 \mathrm{~cm}$ soil texture was set to be sandy clay to account for the relatively strong water holding capacity of grass roots. The diameter of gravel was assumed to be $10 \mathrm{~mm}$.

Using the third set of schemes (the CKJ-G), we tested the effects of gravel diameter $(2 \mathrm{~mm}, 10 \mathrm{~mm}$, and $50 \mathrm{~mm})$ and gravel fraction $(20 \%, 50 \%$, and $80 \%)$ over a soil profile with $1.3 \mathrm{~m}$ mixture of sand and gravel on top of $2.8 \mathrm{~m}$ silty clay.
TCD

$7,4703-4740,2013$

Simulating the role of

gravel on the

dynamics of

permafrost

S. Yi et al.

Title Page

Abstract

Introduction

Conclusions

Tables

References

Figures

14

$\rightarrow I$

4

Back

Close

Full Screen / Esc

Printer-friendly Version

Interactive Discussion 


\section{Results}

\subsection{Effects of gravel on soil properties}

Based on 202 boreholes on the QTP, Nan et al. (2005) used two layers of soil, i.e. silty clay with gravel in the upper part and sand with gravel in the lower part. Therefore, in

5 this study, we presented the thermal and hydraulic properties of mixed silty clay with gravel (Fig. 4) and mixed sand with gravel (Fig. 5).

The simulated effects of gravel on soil thermal and hydraulic properties are striking (Figs. 4 and 5). The porosity of gravel was 0.28 if its representative diameter equales $10 \mathrm{~mm}$. For the mixture of gravel and silty clay (sand), the porosity of the mixture first decreased then increased with increasing gravel content $(\sigma>0)$; the minimum could be as small as $0.12(0.1)$ for an ideal packing $(\sigma=1)$ (Fig. $4 a$ and $5 a)$. With increasing of gravel content, the absolute values of saturated matric potentials (head pressures) decreased logarithmically, which means mixture with more gravel more easily loses soil water (Fig. $4 \mathrm{~b}$ and $5 \mathrm{~b}$ ). The change of the pore size distribution parameter $B$ had little effect on the water retention curve except for very large fraction of gravel content. The effects of gravel on the water retention curve were similar to those from experiments with clay and gravel mixture from Loess Plateau (Wang et al., 2013). Saturated hydraulic conductivity $\left(K_{\text {sat }}\right)$ first decreased then increased with increasing gravel content. The difference can be $\sim 10^{4}$ times (Figs. $4 \mathrm{c}$ and $5 \mathrm{c}$ ). The calculated $K_{\text {sat }}$ was different from that of the CLM. For both unfrozen and frozen mixed silty clay and gravel, the Kersten number $(\mathrm{Ke})$ increased with increasing gravel content (Fig. 4d). However, due to the same parameters in Equation 12 for both sand and gravel, Ke was the same for different gravel contents (Fig. 5d). With increases in gravel content, the dry thermal conductivity $\left(\lambda_{\text {dry }}\right)$ first increased then decreased (Figs. $4 \mathrm{e}$ and $5 \mathrm{e}$ ), which was contrary to the response of porosity. With increases in gravel content, the thermal conductivity $(\lambda)$ increased for both unfrozen and frozen mixed soil (Figs. $4 f$ and $5 f$ ). There were

Simulating the role of gravel on the dynamics of permafrost

S. Yi et al.

Title Page

Abstract Introduction

Conclusions

Tables References

Figures

14 $\Delta$ I

4

Back

Close

Full Screen / Esc

Printer-friendly Version

Interactive Discussion 
thresholds of soil water content that depended on gravel content, below which frozen soil thermal conductivity starts to be smaller than that of unfrozen soil.

\subsection{Comparisons of schemes}

When slope is $0^{\circ}$, no runoff occurred in the perched saturated zone above the thawing 5 front. Therefore, soil was very wet from top to bottom for all three sets of schemes. For simulations using the CLM schemes, heat capacity of sand soil in winter was smaller than that of summer (Table 2). Thermal conductivity and thermal diffusivity in winter were much greater than those in summer (Table 2 and Fig. 6). For both the CKJ and CKJ-G schemes, thermal properties were similar to those of the CLM schemes, however, the differences of thermal conductivity and thermal diffusivities between winter and summer seasons were smaller than the CLM schemes. The simulated mean active layer thicknesses (ALTs) were about 2.13, 1.78 and $2.17 \mathrm{~m}$ using the CLM, CKJ and CKJ-G schemes for three profiles of soil textures $(50,130$ and $210 \mathrm{~cm})$ over the period of 2003-2011, respectively. The simulated permafrost lower boundaries were $34.6,33.5$ and $28.2 \mathrm{~m}$, respectively.

When slope is greater than $0^{\circ}$, runoff occurred in the perched saturated zone above thawing front. For both the CLM and CKJ schemes, which use the same hydrological approach, the simulated soil moistures were similar. For sandy soils, degree of saturation was generally between 0.3 and 0.5 . For simulations with $130 \mathrm{~cm}$ sand and $10^{\circ}$ slope, the thermal diffusivities simulated using the CLM schemes were about $1.63 \times 10^{-6}$ and $0.64 \times 10^{-6} \mathrm{~m}^{2} \mathrm{~s}^{-1}$ in winter and summer, respectively (Table 2 and Figure 6). Those simulated using the CKJ schemes were about $1.11 \times 10^{-6}$ and $0.77 \times 10^{-6} \mathrm{~m}^{2} \mathrm{~s}^{-1}$ in winter and summer, respectively. The simulated degrees of saturation using the CKJ-G schemes were only between 0.04 and 0.12 in the sand 25 (with gravel). For sand with gravel soils, the thermal diffusivities were $0.87 \times 10^{-6}$ and $1.03 \times 10^{-6} \mathrm{~m}^{2} \mathrm{~s}^{-1}$ in winter and summer, respectively. Therefore, the CKJ-G schemes were the only one which simulated smaller thermal diffusivity in winter seasons than in summer seasons. The simulated ALTs/permafrost lower boundaries (PLBs) using the
Simulating the role of gravel on the dynamics of permafrost

S. Yi et al.

Title Page
Abstract

Conclusions

Tables

14

4

Back

Full Screen / Esc

Printer-friendly Version
Close 
CLM schemes slightly decreased/increased with increasing slope (Fig. 7 and 8). The simulated ALTs/PLBs using the CKJ and CKJ-G schemes all increased/decreased with increasing slope. The simulated dynamics of permafrost using the CKJ-G schemes were more sensitive to slope than the CKJ schemes. Permafrost of two simulations 5 (2.1 $\mathrm{m}$ sand with gravel and $5^{\circ}$ and $10^{\circ}$ slopes) using the CKJ-G schemes disappeared (Figs. 7 and 8 ).

The simulated unfrozen thermal diffusivities of silty clay were always smaller than those of sand (with and without gravel) regardless of the schemes used (Fig. 6). In addition, porosity and water holding capacity of silty clay are greater than those of sand (with and without gravel), less latent heat were needed to thaw sand than silty clay. Therefore, ALTs simulated with 3 sets of schemes all increased with increase of thickness of sand (Fig. 7). The simulated PLBs generally decreased with increase of thickness of sand (Fig. 8). For simulations using the CKJ schemes and with slopes, the simulated PLBs first decreased then increased. The simulated soil water degrees of saturation were usually small at bottom of sand soil for the 0.5 and $1.3 \mathrm{~m}$ sand simulations with slopes using the CLM and CKJ schemes. However, for the $2.1 \mathrm{~m}$ sand simulations with the CKJ schemes, sand layers were usually wet (degrees of saturation were greater than 0.4), which caused high thermal diffusivities in winter and deep PLB (figure not shown).

\subsection{Effects of gravel fraction and diameter}

The porosities of mixed sand with gravel decreased with increase of gravel fraction and diameter (Table 3). The minimum was 0.10 with $80 \%$ gravel fraction and $50 \mathrm{~mm}$ diameter; and the maximum was 0.32 with $20 \%$ gravel fraction and $2 \mathrm{~mm}$ diameter. The top $15 \mathrm{~cm}$ soil was specified as mixture of sandy clay and gravel. The porosities were similar to those of sand and gravel mixture. When slope was $0^{\circ}$, degrees of saturation of the top soil with $80 \%$ gravel were less than 0.1 , which was much less than those of simulations with $20 \%$ and $50 \%$ gravel.
Simulating the role of gravel on the dynamics of permafrost

S. Yi et al.

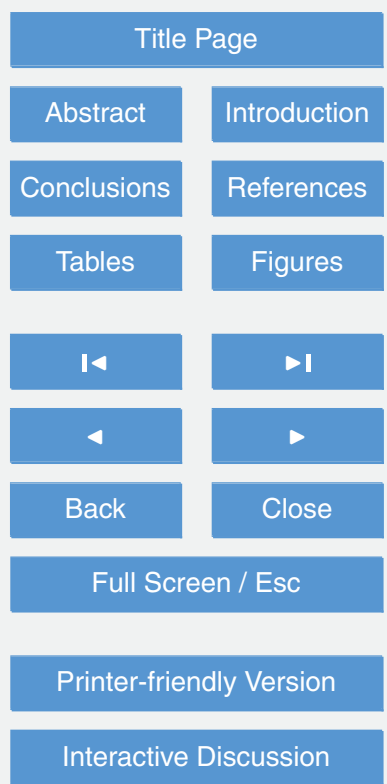


Increase of gravel fraction caused increase of ALT slightly (Fig. 9). For example, the means of ALT of runs with $20 \%$ and $80 \%$ gravel were $\sim 2.05$ and $2.3 \mathrm{~m}$, respectively. Changes of gravel diameter and slope had small effects on ALT. When slope was $0^{\circ}$, the simulated PLB was not sensitive to both gravel fraction and diameter (Fig. 10). 5 However, when slope is greater than $0^{\circ}$, increases of gravel diameter caused increases of PLB when gravel contents were $50 \%$ and $80 \%$; and PLBs were much smaller than those with no slope.

\section{Discussion}

\subsection{Differences of schemes for soil thermal conductivity}

10 The Farouki scheme is widely used in land surface models, e.g. Community Land Model (Oleson et al., 2010) and Noah land model (van der Velde et al., 2009), to simulate soil thermal conductivity. The Farouki scheme always simulated bigger thermal conductivity of frozen soils than unfrozen soils when soil water content is the same (Table 2 and Figure 6). The difference of thermal conductivities between frozen and unfrozen soil increases with increase of soil water content. The combination of Côté and Konrad (2005) and Johanson (1975) schemes simulated bigger thermal conductivity of frozen soil than unfrozen soil with the same soil water content only if the degree of saturation is greater than a threshold. The value is about 0.2 for both silty clay and sand without gravel (Figs. 4 and 5).

Several studies showed that thermal conductivities in winter were slightly greater, or even smaller than those in summer on the QTP. For example, Li et al. (2010) observed smaller thermal conductivity and thermal diffusivity in winter than in summer for top soil at a site on the QTP. Feng et al. (2012) specified the frozen and unfrozen soil thermal conductivities as 1.98 and $1.92 \mathrm{~W} \mathrm{~m}^{-1} \mathrm{~K}^{-1}$, which were derived from borehole

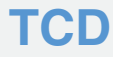

$7,4703-4740,2013$

Simulating the role of

gravel on the

dynamics of

permafrost

S. Yi et al.

Title Page

Abstract

Introduction

Conclusions

Tables

References

Figures

14

$>$ I

4

Back

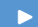

Close

Printer-friendly Version

Interactive Discussion 
to simulate higher unfrozen thermal conductivity than frozen thermal conductivity using the Farouki scheme.

\subsection{Effects of gravel on soil thermal and hydraulic properties}

Soil texture plays an important role in soil thermal and hydraulic properties. For example, organic soil is very common in boreal forests (Yi et al., 2009b). It has high porosity (usually between 0.7 and 0.95 ) and very low thermal conductivity when dry. Therefore, organic soil can slow down the rate of permafrost degradation under a warming climate (Yi et al., 2007). On the QTP, organic soil is relatively rare, but there is a substantial amount of gravel in the soil profile.

The threshold value of degree of saturation, above which frozen soil thermal conductivity is higher than unfrozen, can be as much as 0.6 when the fraction of gravel is $65 \%$. The water holding capacity of soil with gravel is small. Therefore, soil with gravel tends to be dry, the thermal conductivity simulated using the combination of Côté and Konrad (2005) and Johanson (1975) schemes will be smaller in winter than in summer. With a specified constant heat flux at bottom of the $60 \mathrm{~m}$ soil profile, the simulated upward degradation of permafrost is obvious. Our simulation is consistent with Jin et al. (2006), which suggested that the rate of upward degradation of permafrost is faster than downward degradation. The lower boundary of permafrost, rather than active layer thickness, might be a good indicator of permafrost degradation on the QTP. However, most of the current studies on the QTP focus on the latter (e.g. Guo et al., 2012; Li et al., 2012; Pang et al., 2012;), rather than on the former.

The results of this study indicate that gravel plays a very important role in simulated soil thermal and hydraulic properties and in simulated permafrost dynamics. However, gravel fraction and size introduce uncertainties into these properties. Note that we did not consider the effects of root and soil organic carbon, which would reduce soil thermal conductivity in summer (Chen et al., 2012). However, we still underestimated the active layer thickness on the test site. It is possible that the new schemes used in this study might underestimate soil thermal conductivity in summer. More measurements should

Simulating the role of gravel on the dynamics of permafrost

S. Yi et al.

Title Page

Abstract Introduction

Conclusions

Tables References Figures

14 $>$ I

4

Back

Close

Full Screen / Esc

Printer-friendly Version

Interactive Discussion 
be made to test the scheme of this study or to develop more suitable thermal schemes for the Qinghai-Tibetan Plateau.

\subsection{Spatial and vertical distribution of gravel}

Gravel is common in soil profiles on the QTP. However, there is no information about 5 the spatial and vertical distribution of gravel at the plateau scale. Based on limited field data, the distribution of gravel has large spatial and vertical heterogeneities. For example, the soil profile of Beiluhe region consists of $0.5-2.1 \mathrm{~m}$ sand with gravel on top of $<8 \mathrm{~m}$ silty clay (Lin et al., 2011). The surface soil of the Beiluhe site also has large differences of gravel contents (Yang et al., 2009). Surface soil along the Qinghai-Tibetan

10 Railway varies from sandy clay, to clay, to clay with gravel, and to gravel with sandy silt (Wu et al., 2012; Xie et al., 2012). In Suli, which is located in the north-east of the QTP, gravel is also common (Fig. 11a and b). To realistically simulate changes of permafrost, more effort should be made to compile spatial datasets of the vertical distribution of gravel content based on measurements made during drilling or the digging of soil pits.

\subsection{Temporal change of gravel}

Gravel also plays an important role in alpine grassland ecosystems. Wang et al. (2011) found that gravel mulch increases infiltration, decreases evaporation and runoff, and benefits for accumulation of grassland soil in arid regions on the QTP. While Yang et al. (2009) and Wu et al. (2011) found that grassland biomass is negatively related the gravel content on sites on the QTP. In our study, the simulated surface soil water content became low only when gravel fraction increased to $80 \%$, which might affect the productivity of grassland.

Under the combined effects of animal disturbances (e.g. overgrazing and rodents), strong erosions and human tillage, the fraction of gravel in soil may change in a few years. For example, in a research site of Suli, two pits were dug in 2013 (Fig. 11c),

Simulating the role of gravel on the dynamics of permafrost

S. Yi et al.

Title Page

Abstract Introduction

Conclusions

Tables References

Figures

14 $\rightarrow \mathrm{I}$

4

Back

Close

Full Screen / Esc

Printer-friendly Version

Interactive Discussion 
one on alpine meadow grassland with small disturbances from plateau pika (Ochotona curzoniae) and soil erosion; the other on heavily eroded and tilled grassland. Both grasslands are flat. There is large amount of gravel in the soil profile on the eroded and tilled grassland; while in the soil profile of relatively undisturbed meadow grassland, 5 there are lots of root and fine soil in the top $40 \mathrm{~cm}$. In June 2013, we found no frozen soil down to $1.3 \mathrm{~m}$ in the eroded and tilled grassland; however, we found frozen soil at a depth of about $0.4 \mathrm{~m}$ in the undisturbed grassland. Since the distance between two pits is less than $300 \mathrm{~m}$, the climate of both grasslands should be the same. The large difference in soil thermal state is most likely related to changes of topsoil, which should be considered in the simulation of vegetation production.

\section{Conclusions}

Gravel is common in soil profiles on the QTP. However, few models have considered gravel. In this study, we implemented the thermal and hydraulic properties of gravel into the dynamic organic soil version of Terrestrial Ecosystem Model; and compared 15 the simulated active layer and permafrost dynamics among different schemes. Results showed that soil with gravel tended to be dry, when subsurface drainage occurred. There exists a threshold, below which the new set of schemes with gravel simulated smaller thermal conductivity of frozen soils than unfrozen soils with the same soil water content. The new set of schemes simulated faster upward degradation than downward degradation, which is consistent with Jin et al. (2006). However, the simulated permafrost thicknesses were sensitive to the fraction of gravel, gravel size, thickness of the soil with gravel and slope. To reduce the uncertainties caused by gravel, future studies should focus on establishing relationships between the thermal and hydraulic properties of mixed soil with gravel fraction and size, and on compiling spatial datasets

Acknowledgements. We would like to thank Dave McGuire of University of Alaska Fairbanks for improving English. This study was jointly supported by grants from the Major State Ba4721
TCD

7, 4703-4740, 2013

Simulating the role of gravel on the dynamics of permafrost

S. Yi et al.

Title Page

Abstract Introduction

Conclusions

Tables References Figures

14 $\rightarrow 1$

4

Back

Close

Full Screen / Esc

Printer-friendly Version

Interactive Discussion 
sic Research Development Programme of China (973 Programme) (No 2010 CB951402 and 2013CBA01807), the Strategic Priority Research Program (XDB030303), the One Hundred People Plan of the Chinese Academy of Sciences $(0927581001)$ and the Chinese National Natural Science Foundation Commission (41271089), and by independent grants from State 5 Key Laboratory of Cryospheric Sciences (SKLCS-ZZ-2012-2-2).

\section{References}

Arocena, J., Hall, K., and Zhu, L. P.: Soil formation in high elevation and permafrost areas in the Qinghai Plateau (China), Spanish Journal of Soil Sciences, 2, 34-49, 2012.

Chen, Y., Yang, K., Tang, W., Qin, J., and Zhao, L.: Parameterizing soil organic carbon's impacts on soil porosity and thermal parameters for Eastern Tibet grasslands, Sci. China Ser. D, 55, 1001-1011, 2012.

Clapp, R. B. and Hornberger, G. M.: Empirical Equations for some soil hydraulic properties, Water Resour. Res., 14, 601-604, 1978.

Cosby, J. B., Hornberger, G. M., Clapp, R. B., and Ginn, T. R.: A statistical exploration of the relationships of soil moisture characteristics to the physical properties of soils, Water Resour. Res., 20, 682-690, 1984.

Côté, J. and Konrad, J.: A generalized thermal conductivity model for soils and construction materials, Can. Geotech. J., 42, 443-458, 2005.

Fan, Y., Liu, S., Zhang, S., and Deng, L.: Background organic carbon storage of topsoil and whole profile of soils from Tibet District and their spatial distribution, Acta Ecologica Sinica., 26, 2834-2846, 2006 (in Chinese with English abstract).

Feng, W., Ma, W., Wen, Z., Zhang, Z., Li, G., Yu, W., Sun, Z., and Koemle, N.: Numerical model for the variation of the frost boundary below embankments using surface temperature and net radiation data, Cold Regions Engineering, 552-562, doi:10.1061/9780784412473.055, 252012.

Frings, R. M., Schüttrumpf, H., and Vollmer, S.: Verification of porosity predictors for fluvial sandgravel deposits, Water Resour. Res., 47, W07525, doi:10.1029/2010WR009690, 2011.

Gubler, S., Endrizzi, S., Gruber, S., and Purves, R. S.: Sensitivities and uncertainties of modeled ground temperatures in mountain environments, Geosci. Model Dev., 6, 1319-1336,
TCD

$7,4703-4740,2013$

Simulating the role of gravel on the dynamics of permafrost

S. Yi et al.

Title Page
Abstract

Conclusions

Tables

14

4

Back
Introduction

References

Figures

$>1$

$>$

Close
Full Screen / Esc

Printer-friendly Version

Interactive Discussion 
Guo, D., Wang, H., and Li, D.: A projection of permafrost degradation on the Tibetan Plateau during the 21st century, J. Geophys. Res., 117, D05106, doi:10.1029/2011JD016545, 2012.

Jin, H., Zhao, L., Wang, S., Guo, D.: Evolution of permafrost and changes in cold regions environments on eastern and interior Qinghai-Tibet Plateau, Quaternary Sci., 26, 198-210, 52006.

Jin, H., Luo, D., Wang, S., Lv, L., and Wu, J.: Spatialtemporal variability of permafrost degradation on the Qinghai-Tibetan Plateau, Sciences in Cold and Arid Regions, 3, 281-305, 2011.

Johansen, O.: Thermal conductivity of soils, Ph.D. thesis, Trondheim, University of Trondheim, 1975.

10 Li, R., Zhao, L., Ding, Y., Jiao, K., Wang, Y., Qiao, Y., Du, E., Liu, G., Sun, L., and Xiao, Y.: A study on soil thermodynamic characteristics of active layer in northern Tibetan Plateau, Chinese J. Geophys.-Ch., 53, 1060-1072, 2010 (in Chinese with English abstract).

Li, R., Zhao, L., Ding, Y., Wu, T., Xiao, Y., Du, E., Liu, G. and Qiao, Y.: Temporal and spatial variations of the active layer along the Qinghai-Tibet Highway in a permafrost region, Chinese

$\mathrm{Li}, \mathrm{S}$. and Cheng, G.: Map of permafrost distribution on the Qinghai-Xizang (Tibetan) Plateau $(1: 3,000,000)$ [in Chinese], Gansu Cultural Press, Lanzhou, 1996.

Lin, Z., Niu, F., Liu, H., and Lu, J.: Hydrothermal processes of alpine tundra lakes, Beiluhe Basin, Qinghai-Tibet Plateau, Cold Reg. Sci. Technol., 65, 446-455, 2011.

20 Luo, S., Lv, S., Zhang, Y., Hu, Z., Ma, Y., Li, S., and Shang, L.: Soil thermal conductivity parameterization establishment and application in numerical model of central Tibetan Plateau, Chinese J. Geophys.-Ch., 52, 919-928, 2009 (in Chinese with English abstract).

Nan, Z., Li, S., and Cheng, G.: Prediction of permafrost distribution on the Qinghai-Tibet Plateau in the next 50 and 100 years, Sci. China Ser. D, 48, 797-804, 2005.

Oleson, K. W., Lawrence, D. M., Bonan, G. B., Flanner, M. G., Kluzek, E., Lawrence, P. J., Levis, S., Swenson, S. C., and Thornton, P.: Technical description of version 4.0 of the Community Land Model (CLM), NCAR 2153-2400, University Corporation for Atmospheric Research, 2010.

Pang, Q., Zhao, L., Li, S., and Ding, Y.: Active layer thickness variations on the Qinghai-Tibet Plateau under the scenarios of climate change, Environ. Earth Sci., 66, 849-857, 2012.

Qin, Y., Hiller, J. E., Jiang, G., and Bao, T.: Sensitivity of thermal parameters affecting coldregion ground-temperature predictions, Environ. Earth Sci., 68, 1757-1772, 2013.
TCD

$7,4703-4740,2013$

Simulating the role of

gravel on the

dynamics of

permafrost

S. Yi et al.

Title Page

Abstract

Introduction

Conclusions

Tables

References

Figures

14

4

Back

Close

Full Screen / Esc

Printer-friendly Version

Interactive Discussion 
Stephens, D. B., Hsu, K., Prieksat, M. A., Ankeny, M. D., Blandford, N., Roth, T. L., Kelsey, J. A., and Whitworth, J. R.: A comparison of estimated and calculated effective porosity, Hydrogeol. J., 6, 156-165, 1998.

Swenson, S. C., Lawrence, D. M., and Lee, H.: Improved Simulation of the Terrestrial Hydrolog5 ical Cycle in Permafrost Regions by the Community Land Model, J. Adv. Model. Earth Syst., 4, M08002, doi:10.1029/2012MS000165, 2012.

Tan, K., Ciais, P., Piao, S., Wu, X., Tang, Y., Vuichard, N., Liang, S., and Fang, J.: Application of the ORCHIDEE global vegetation model to evaluate biomass and soil carbon stocks of Qinghai-Tibetan grasslands, Global Biogeochem. Cy., 24, GB1013, doi:10.1029/2009GB003530, 2010.

van der Velde, R., Su, Z., Ek, M., Rodell, M., and Ma, Y.: Influence of thermodynamic soil and vegetation parameterizations on the simulation of soil temperature states and surface fluxes by the Noah LSM over a Tibetan plateau site, Hydrol. Earth Syst. Sci., 13, 759-777, doi:10.5194/hess-13-759-2009, 2009.

Wang, H., Xiao, B.,Wang, M., and Shao, M.: Modeling the soil water retention curves of soilgravel mixtures with regression method on the Loess Plateau of China, PLoS ONE, 8, e59475, doi:10.1371/journal.pone.0059475, 2013.

Wang, X., Liu, G., and Liu, S.: Effects of gravel on grassland soil carbon and nitrogen in the arid regions of the Tibetan Plateau, Geoderma, 166, 181-188, 2011.

20 Wright, N., Hayashi, M., and Quinton, W. L.: Spatial and temporal variations in active layer thawing and their implication on runoff generation in peat-covered permafrost terrain, Water Resour. Res., 45, W05414, doi:10.1029/2008WR006880, 2009.

Wu, W. and Wang, S.: Formulas for sediment porosity and settling velocity, J. Hydraul. Eng.ASCE, 132, 858-862, 2006.

Wu, Q. and Zhang, T.: Recent permafrost warming on the Qinghai-Tibetan Plateau, J. Geophys. Res., 113, D13108, doi:10.1029/2007JD009539, 2008.

$\mathrm{Wu}, \mathrm{Q}$. and Zhang, T.: Changes in active layer thickness over the Qinghai-Tibetan Plateau from 1995 to 2007, J. Geophys. Res., 115, D09107, doi:10.1029/2009JD012974, 2010.

Wu, Q., Cheng, G., and Ma, W..: Impact of permafrost change on the Qinghai-Tibet Railraod engineering, Sci. China Ser. D, 47, 122-130, 2004.

Wu, Q., Zhang, T., and Liu, Y.: Thermal state of the active layer and permafrost along the Qinghai-Xizang (Tibet) Railway from 2006 to 2010, The Cryosphere, 6, 607-612, doi:10.5194/tc-6-607-2012, 2012.
TCD

7, 4703-4740, 2013

Simulating the role of gravel on the dynamics of permafrost

S. Yi et al.

Title Page

Abstract

Introduction

Conclusions

References

Tables

Figures

14

I

4

Back

$>$

Close

Full Screen / Esc

Printer-friendly Version

Interactive Discussion 
Wu, X., Zhao, L., Fang, H., Chen, J., Pang, Q., Wang, Z., Chen, M., and Ding, Y.: Soil enzyme activities in permafrost regions of the Western Qinghai-Tibetan Plateau, Soil Biol. Biochem., 76, 1280-1289, 2011.

Xie, C., Zhao, L., Wu, T., and Dong, X.: Changes in the thermal and hydraulic regime within the active layer in the Qinghai-Tibet Plateau, J. Mt. Sci., 9, 483-491, 2012.

Yang, J., Mi, R., and Liu, J.: Variations in soil properties and their effect on subsurface biomass distribution in four alpine meadows of the hinterland of the Tibetan Plateau of China, Environ. Geol., 57, 1881-1891, 2009.

Ye, B., Yang, D., Zhang, Z., and Kane, D. L.: Variation of hydrological regime with permafrost coverage over Lena Basin in Siberia, J. Geophys. Res., 114, D07102, doi:10.1029/2008JD010537, 2009.

Yi, S., Woo, M.-K., and Arain, A. M.: Impacts of peat and vegetation on permafrost degradation under climate warming, Geophys. Res. Lett., 34, L16504, doi:10.1029/2007GL030550, 2007.

15 Yi, S., McGuire, A. D., Harden, J., Kasischke, E., Manies, K. L., Hinzman, L. D., Liljedahl, A.,Randerson, J. T., Liu, H., Romanovsky, V. E., Marchenko, S., and Kim, Y.: Interactions between soil thermal and hydrological dynamics in the response of Alaska ecosystems to fire disturbance, J. Geophys. Res., 114, G02015, doi:10.1029/2008JG000841, 2009a.

Yi, S., Manies, K. L., Harden, J., and McGuire, A. D.: The characteristics of organic soil in black spruce forests: Implications for the application of land surface and ecosystem models in cold regions, Geophys. Res. Lett., 36, L05501, doi:10.1029/2008GL037014, 2009b.

Yi, S., McGuire, A. D., Kasischke, E., Harden, J., Manies, K. L., Mack, M., and Turetsky, M. R.: A Dynamic organic soil biogeochemical model for simulating the effects of wildfire on soil environmental conditions and carbon dynamics of black spruce forests, J. Geophys. Res., 115, G04015, doi:10.1029/2010JG001302, 2010.

Yi, S., Zhou, Z., Ren, S., Xu, M., Qin, Y., Chen, S., and Ye, S.: Effects of permafrost degradation on alpine grassland in a semi-arid basin on the Qinghai-Tibetan Plateau, Environ. Res. Lett., 6, 045403, doi:10.1088/1748-9326/6/4/045403, 2011.

Yi, S., Wischnewski, K., Langer, M., Muster, S., and Boike, J.: Modeling different freeze/thaw processes in heterogeneous landscapes of the Arctic polygonal tundra using an ecosystem model, Geosci. Model Dev. Discuss., 6, 4883-4932, doi:10.5194/gmdd-6-4883-2013, 2013a.

Simulating the role of gravel on the dynamics of permafrost

S. Yi et al.

Title Page

Abstract

Conclusions

Tables

14

4

Back

Full Screen / Esc

Printer-friendly Version

\section{Close}


Yi, S., Li, N., Xiang, B., Ye, B., and McGuire, A. D.: Representing the effects of alpine grassland vegetation cover on the simulation of soil thermal dynamics by ecosystem models applied to the Qinghai-Tibetan Plateau, J. Geophys. Res., 118, 1-14, doi:10.1002/jgrg.20093, 2013b.

Yuan, F., Yi, S., McGuire, A. D., Johnsen, K. H., Liang, J., Harden, J., and Kasischke, E.: Assess5 ment of historical boreal forest $\mathrm{C}$ dynamics in Yukon River Basin: Relative roles of warming and fire regime change, Ecol. Appl., 22, 2091-2109, 2012.

Zhang, Y., Wang, X., Fraser, R., Olthof, I., Chen, W., Mclennan, D., Ponomarenko, S., and Wu, W.: Modelling and mapping climate change impacts on permafrost at high spatial resolution for an Arctic region with complex terrain, The Cryosphere, 7, 1121-1137, doi:10.5194/tc-71121-2013, 2013.

Zhang, Z. F., Ward, A. L., and Keller, J. M.: Determining the porosity and saturated hydraulic conductivity of binary mixtures, Vadose Zone J., 10, 313-321, 2011.

Zhuang, Q., He, J., Lu, Y., Ji, L., Xiao, J., and Luo, T.: Carbon dynamics of terrestrial ecosystems on the Tibetan Plateau during the 20th century: an analysis with a process-based biogeochemical model, Global Ecol. Biogeogr., 19, 649-662, 2010.

Simulating the role of

gravel on the

dynamics of

permafrost

S. Yi et al.

Title Page

Abstract

Conclusions

Tables

14

4

Back
Introduction

References

Figures

$\Delta$

Close

Full Screen / Esc

Printer-friendly Version

Interactive Discussion 
Table 1. Comparison of three sets of schemes that were tested in this study.

\begin{tabular}{llll}
\hline & Porosity & Thermal properties & Hydraulic properties \\
\hline CLM & Farouki (1981) & Farouki (1981) & $\begin{array}{l}\text { Clapp and } \\
\text { Hornberger (1978); } \\
\text { Cosby et al. (1984) }\end{array}$ \\
CKJ & As CLM & $\begin{array}{l}\text { Côté and Konrad (2005), } \\
\text { As CLM }\end{array}$ \\
CKJ- & Zhang et al. (2011); & As CKJ, but with gravel & $\begin{array}{l}\text { As CLM, but with gravel } \\
\text { and with saturated hy- } \\
\text { araulic conductivity from } \\
\text { Zhang et al. (2011) }\end{array}$ \\
& Wu and Wang (2006) & & $\begin{array}{l}\text { Zhang } \\
\end{array}$
\end{tabular}

TCD

$7,4703-4740,2013$

Simulating the role of gravel on the dynamics of permafrost

S. Yi et al.

Title Page
Abstract

Conclusions

Tables

14

Back

\section{Full Screen / Esc}

Printer-friendly Version 
Table 2. Comparison of soil thermal properties calculated in three different sets of schemes (the CLM, CKJ and CKJ-G, see Table 1) for $130 \mathrm{~cm}$ sand (with and without gravel) with $0^{\circ}$ and $10^{\circ}$ slope during winter (December-Feburary, Frozen) and summer seasons (June-August, Unfrozen) over the period of 2003-2011.

\begin{tabular}{|c|c|c|c|c|c|c|c|}
\hline \multirow[t]{2}{*}{ Slope } & \multirow[t]{2}{*}{ Schemes } & \multicolumn{2}{|c|}{$\begin{array}{c}\text { Thermal } \\
\text { Conductivity } \\
\left(\mathrm{W} \mathrm{m}^{-1} \mathrm{~K}^{-1}\right)\end{array}$} & \multicolumn{2}{|c|}{$\begin{array}{c}\text { Volumetric Heat } \\
\text { Capacity } \\
\left(\mathrm{MJ} \mathrm{m}^{-3} \mathrm{~K}^{-1}\right)\end{array}$} & \multicolumn{2}{|c|}{$\begin{array}{c}\text { Thermal } \\
\text { diffusivity } \\
\left(10^{-6} \mathrm{~m}^{2} \mathrm{~s}^{-1}\right)\end{array}$} \\
\hline & & Unfrozen & Frozen & Unfrozen & Frozen & Unfrozen & Frozen \\
\hline \multirow[t]{3}{*}{$0^{\circ}$} & CLM & 4.76 & 7.88 & 4.31 & 3.11 & 1.10 & 2.54 \\
\hline & CKJ & 2.90 & 4.70 & 4.23 & 3.11 & 0.69 & 1.51 \\
\hline & CKJ-G & 3.99 & 4.82 & 3.75 & 3.16 & 1.06 & 1.52 \\
\hline \multirow[t]{3}{*}{$10^{\circ}$} & CLM & 1.93 & 4.00 & 3.00 & 2.46 & 0.64 & 1.63 \\
\hline & CKJ & 2.32 & 2.73 & 3.00 & 2.45 & 0.77 & 1.11 \\
\hline & CKJ-G & 3.03 & 2.39 & 2.96 & 2.74 & 1.03 & 0.87 \\
\hline
\end{tabular}

Simulating the role of

gravel on the

dynamics of

permafrost

S. Yi et al.

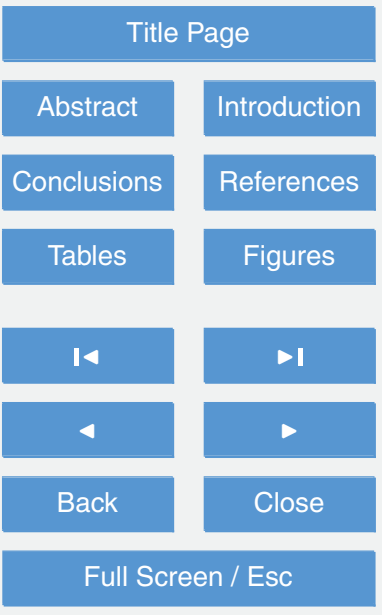

Printer-friendly Version

Interactive Discussion 
Table 3. Porosities $\left(\mathrm{m}^{3} \mathrm{~m}^{-3}\right)$ of soil mixture of sand and gravel with different fractions and diameters.

\begin{tabular}{lccc}
\hline & $20 \%$ & $50 \%$ & $80 \%$ \\
\hline $2 \mathrm{~mm}$ & 0.32 & 0.24 & 0.24 \\
$10 \mathrm{~mm}$ & 0.30 & 0.19 & 0.13 \\
$50 \mathrm{~mm}$ & 0.30 & 0.19 & 0.10 \\
\hline
\end{tabular}

Simulating the role of gravel on the dynamics of permafrost

S. Yi et al.

\section{Title Page}

Abstract

Conclusions

Tables

14

4

Back

Full Screen / Esc

Printer-friendly Version

Interactive Discussion 


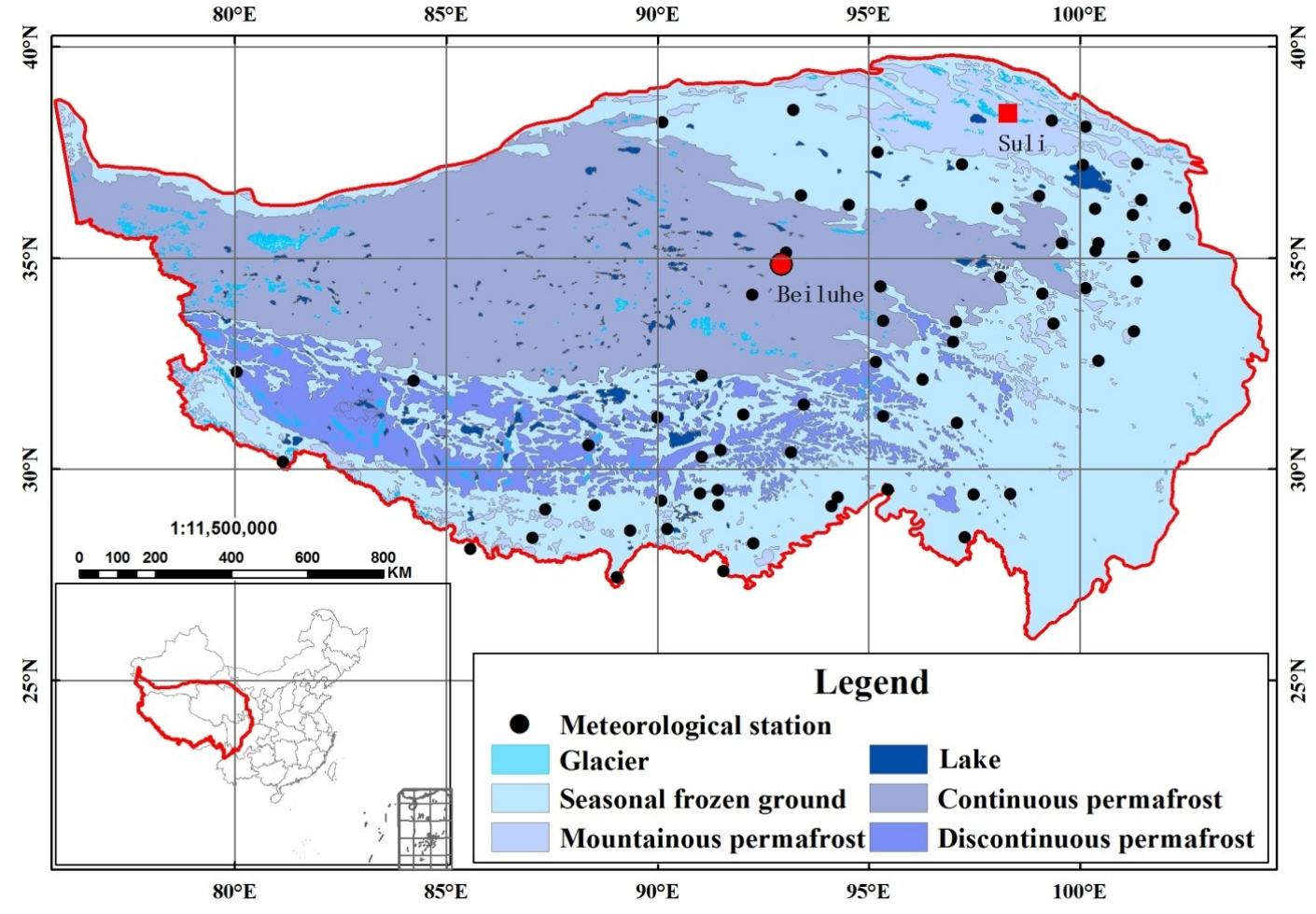

Fig. 1. Spatial distribution of meteorological stations (black dots), and the locations of the Beiluhe permafrost station (red dot) and soil sampling station in Suli (red square) on the Qinghai-Tibetan Plateau used in this study (Permafrost type is from Li and Cheng, 1996).

\section{TCD}

$7,4703-4740,2013$

Simulating the role of gravel on the dynamics of permafrost

S. Yi et al.

\section{Title Page}

Abstract

Conclusions

Tables

14

Back
Introduction

References
$>1$

Close

\section{Full Screen / Esc}

Printer-friendly Version 

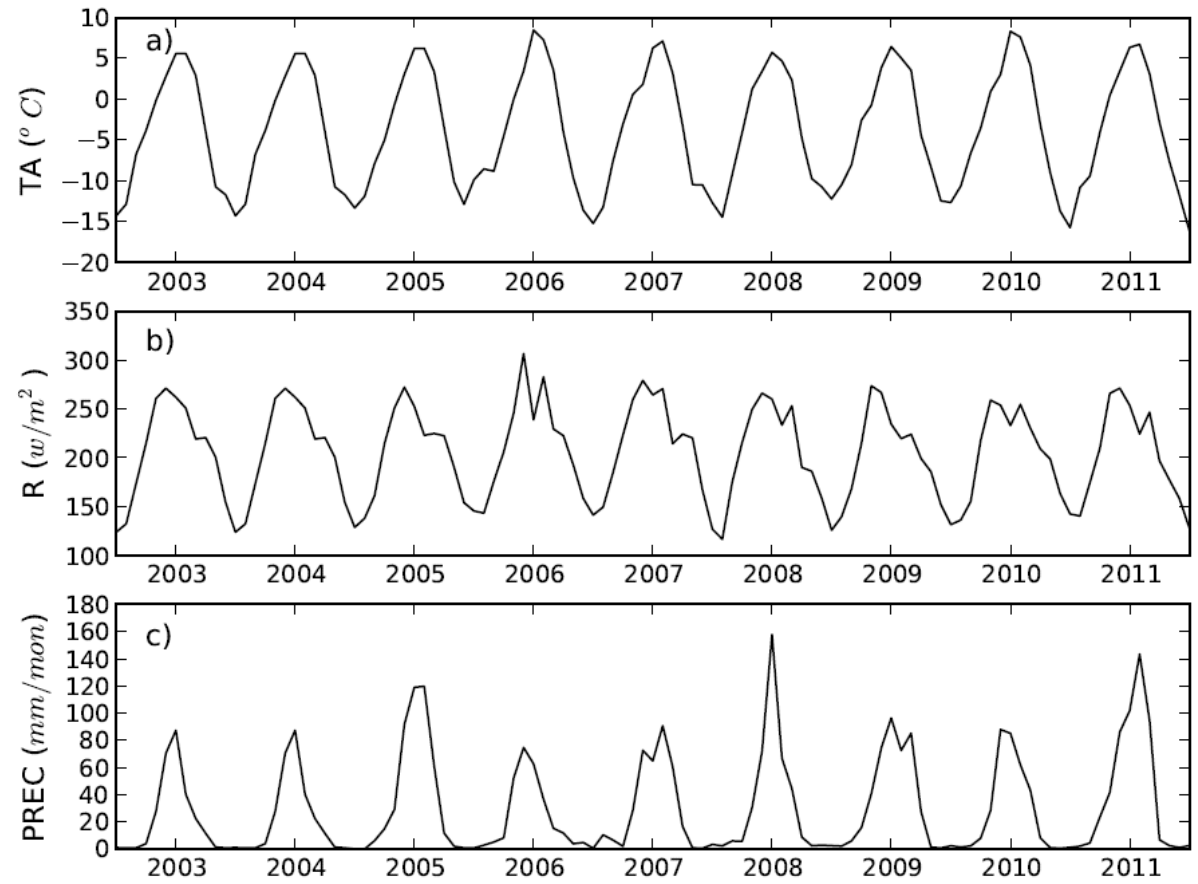

Fig. 2. (a) air temperature (TA); (b) downward solar radiation ( $R$ ); and (c) precipitation (PREC) measured on Beiluhe Permafrost Station on the Qinghai-Tibet Plateau from 2003 to 2011.
TCD

$7,4703-4740,2013$

Simulating the role of gravel on the dynamics of permafrost

S. Yi et al.

\section{Title Page}

\section{Abstract}

Conclusions

Tables

14

Back
Introduction

References

Figures

$>$ I

Close

\section{Full Screen / Esc}

Printer-friendly Version

Interactive Discussion 

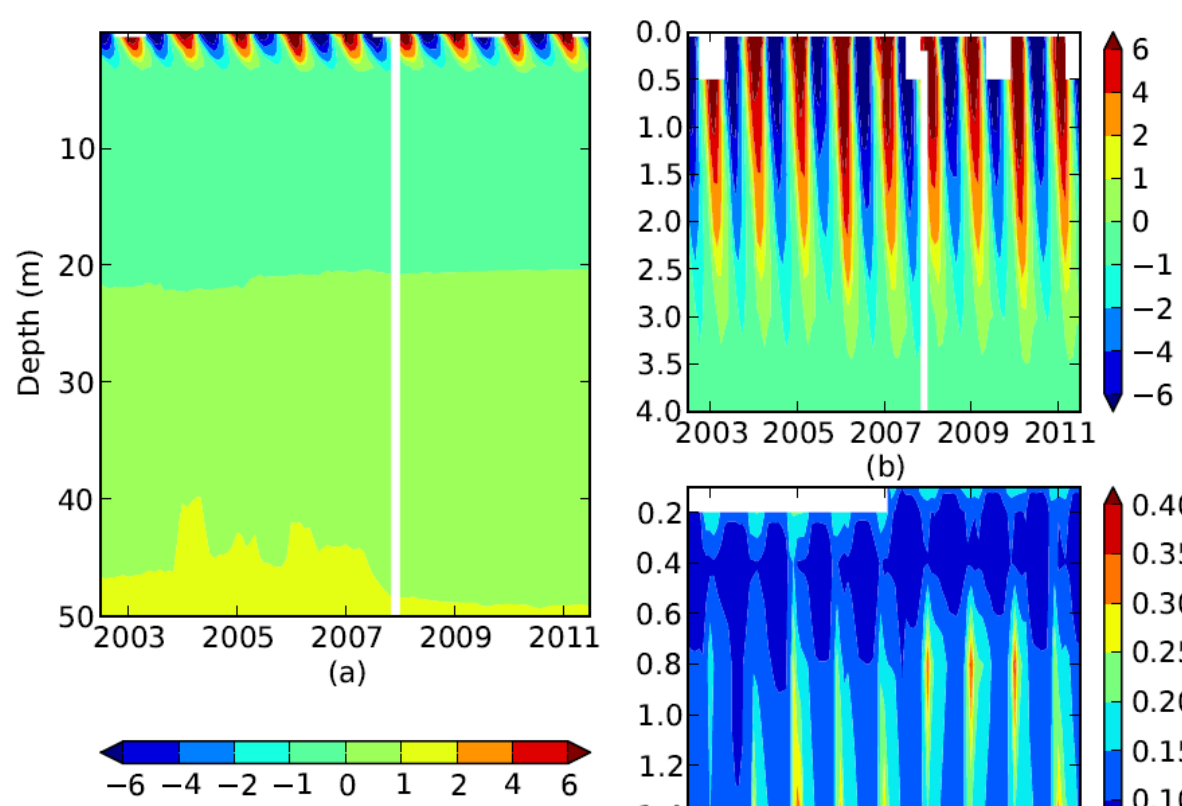

TCD

7, 4703-4740, 2013

Simulating the role of gravel on the dynamics of permafrost

S. Yi et al.

Title Page

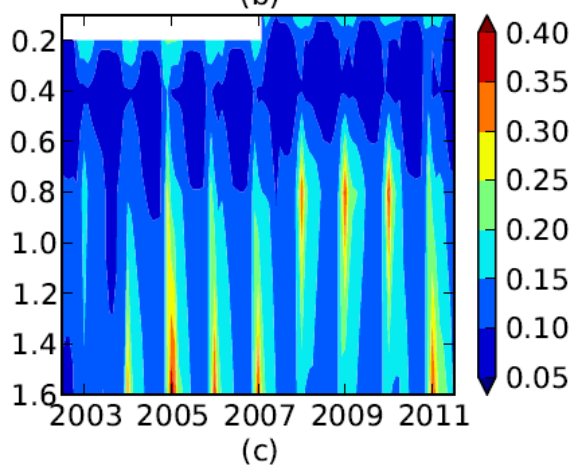

Abstract

Introduction

Conclusions

References

Tables

Figures

14

$\rightarrow 1$

4

$>$

Back

Close

Full Screen / Esc

Printer-friendly Version

Interactive Discussion 

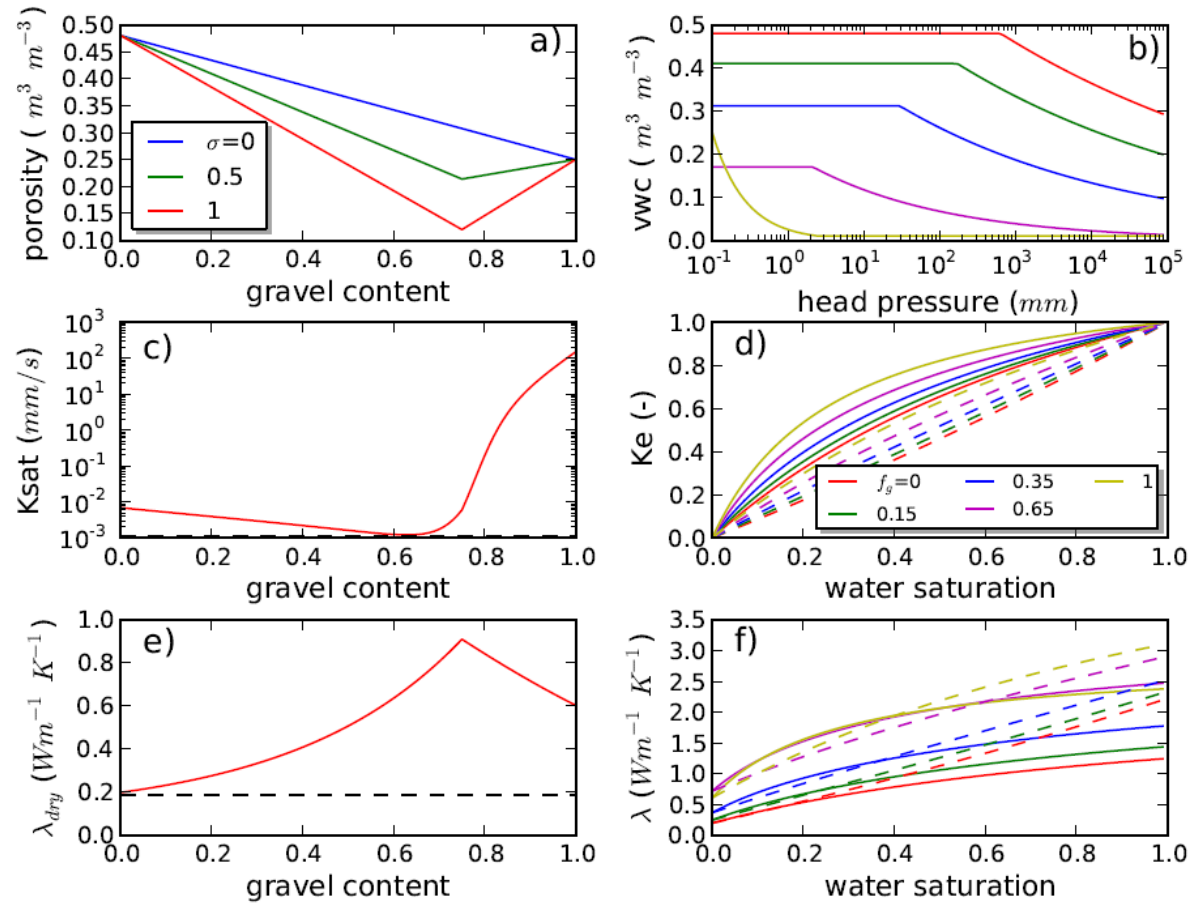

Fig. 4. (a) Effects of gravel content on porosity of mixed silty clay and gravel with no mixing $(\sigma=0)$, half mixing (0.5), and ideal mixing (1); (b) effects of gravel content (red: no gravel, green: $15 \%$, blue: $35 \%$, magenta: $65 \%$ and yellow: $100 \%$ ) on water retention curve of soil mixture; (c) Effects of gravel content on saturated hydraulic conductivity (Ksat); black dashed line indicates the value of silty clay calculated by the Community Land model; (d) response of the relations between the Kestern number $(\mathrm{Ke})$ and water saturation to gravel content; solid and dashed lines are for unfrozen and frozen soil, respectively; (e) Effects of gravel content on dry thermal conductivity $\left(\lambda_{\text {dry }}\right)$, black dashed line indicates the value of silty clay calculated by Community Land Model; and (f) same as (d) but for thermal conductivity $(\lambda)$.
TCD

$7,4703-4740,2013$

Simulating the role of

gravel on the

dynamics of

permafrost

S. Yi et al.

Title Page

Abstract

Introduction

Conclusions

References

Tables

Figures

14

$>1$

4

Back

Close

Full Screen / Esc

Printer-friendly Version

Interactive Discussion 


\section{7, 4703-4740, 2013}
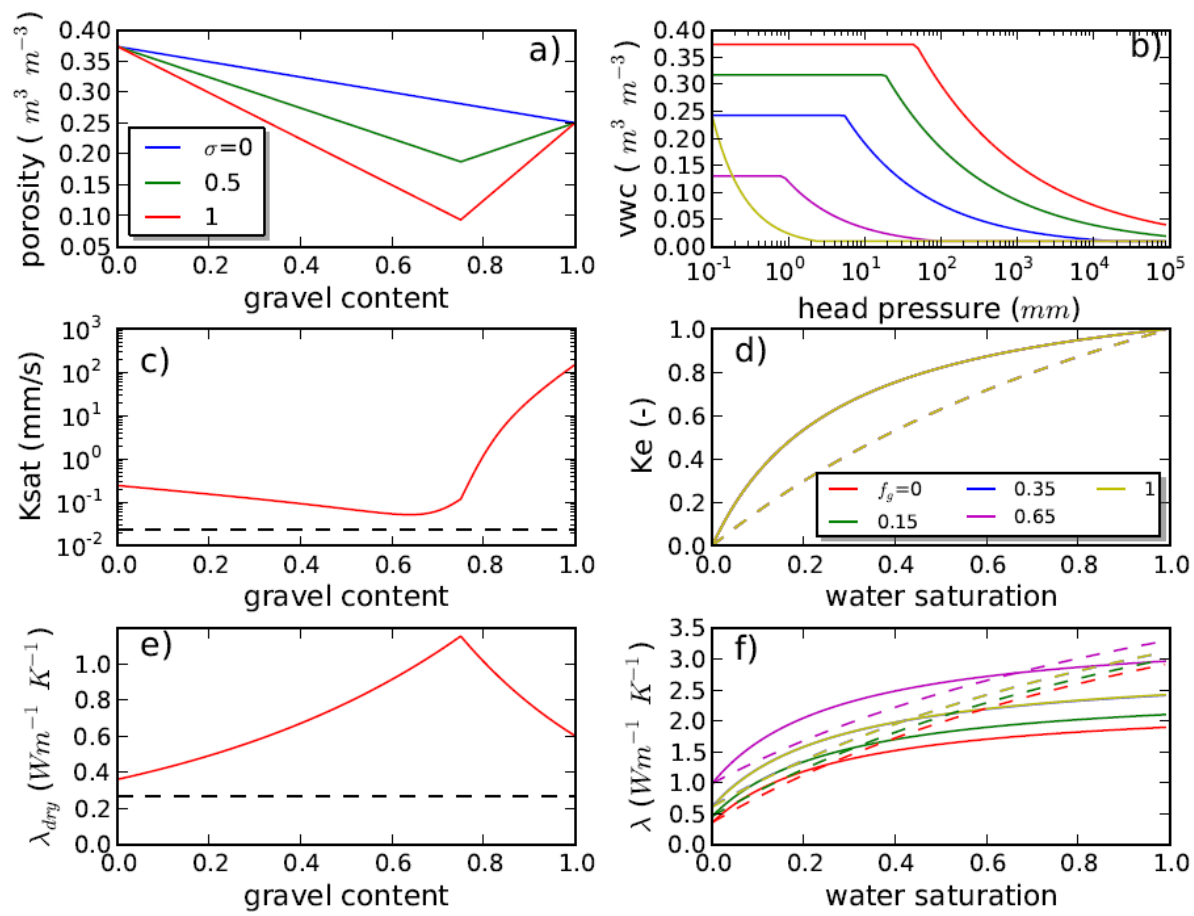

Simulating the role of gravel on the dynamics of permafrost

S. Yi et al.

Title Page

Abstract

Introduction

Conclusions

References

Tables

Figures

14

$>$ I

4

Back

Close

Full Screen / Esc

Printer-friendly Version

Interactive Discussion 

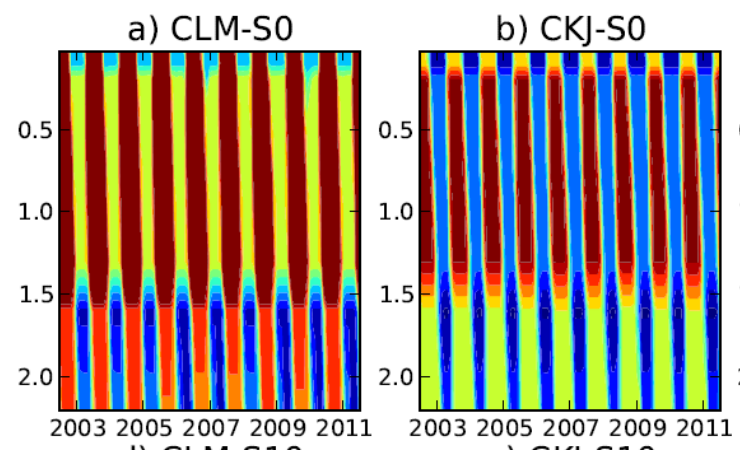

e) CKJ-S10
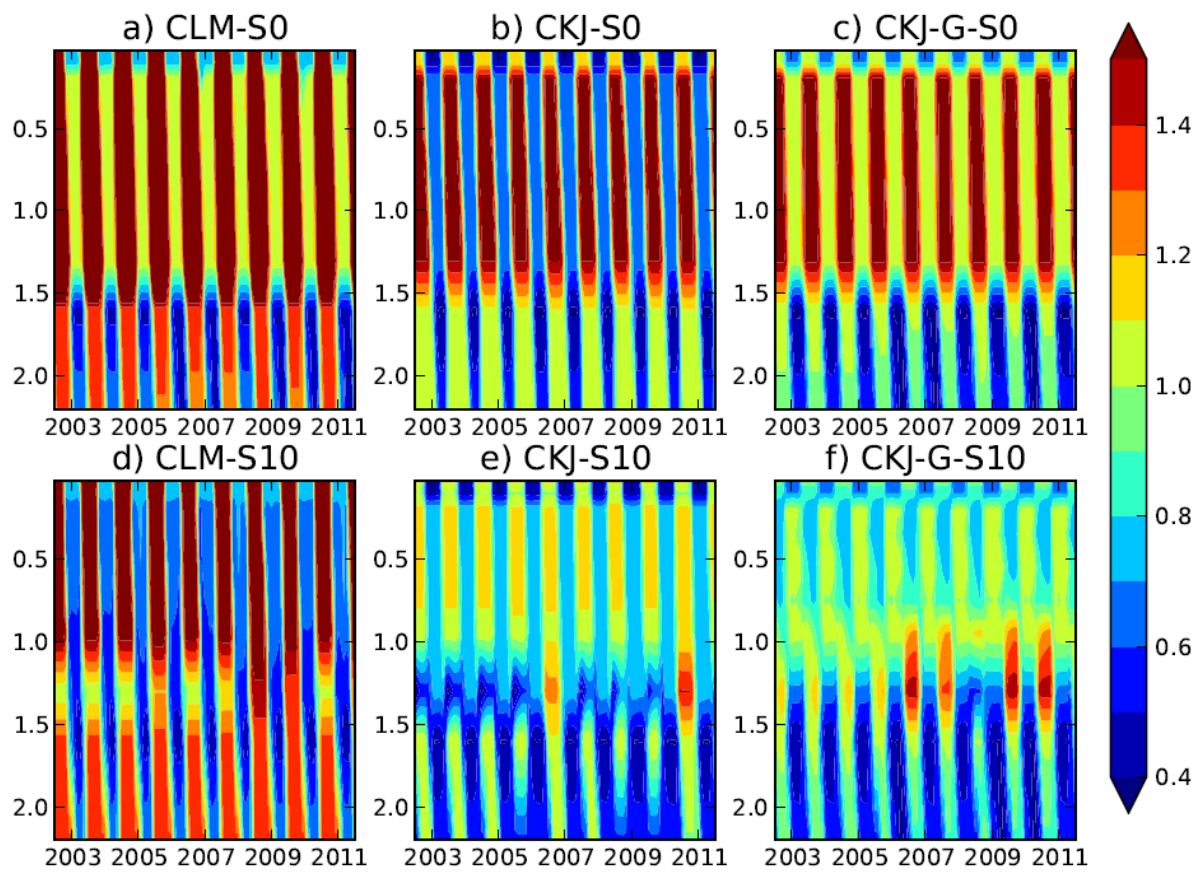

Fig. 6. Contour of simulated soil thermal diffusivities $\left(10^{-6} \mathrm{~m}^{2} \mathrm{~s}^{-1}\right)$ using the CLM, CKJ, and CKJ-G set of schemes (Table 1) with $0^{\circ}$ (SO) and $10^{\circ}$ (S10) slopes. The top $15 \mathrm{~cm}$ of soil consists of sandy clay with gravel; $15-130 \mathrm{~cm}$ sand with gravel; and $130-210 \mathrm{~cm}$ silty clay.
TCD

$7,4703-4740,2013$

Simulating the role of gravel on the dynamics of permafrost

S. Yi et al.

\section{Title Page}

14

$\rightarrow \mathrm{I}$

4

$>$

\section{Back}

Close

\section{Full Screen / Esc}

Printer-friendly Version

Interactive Discussion 
a) CLM

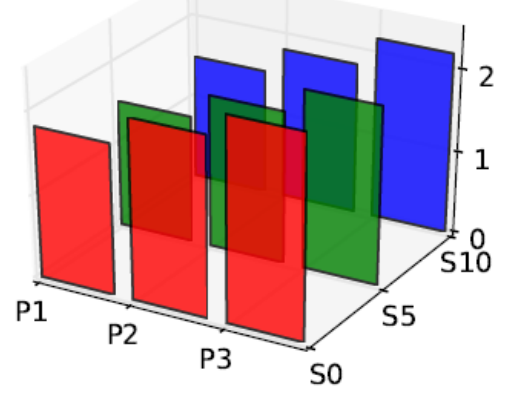

c) $\mathrm{CKJ}-\mathrm{G}$

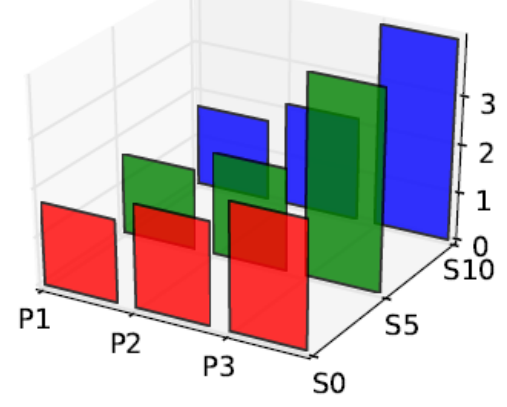

b) $\mathrm{CKJ}$

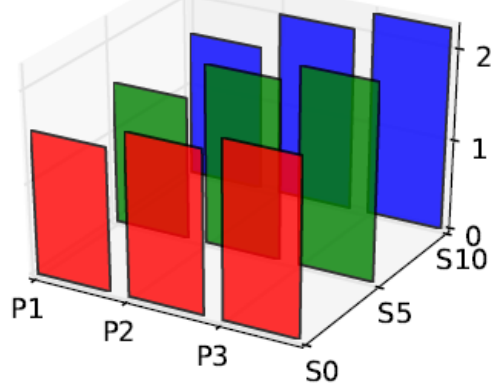

d)

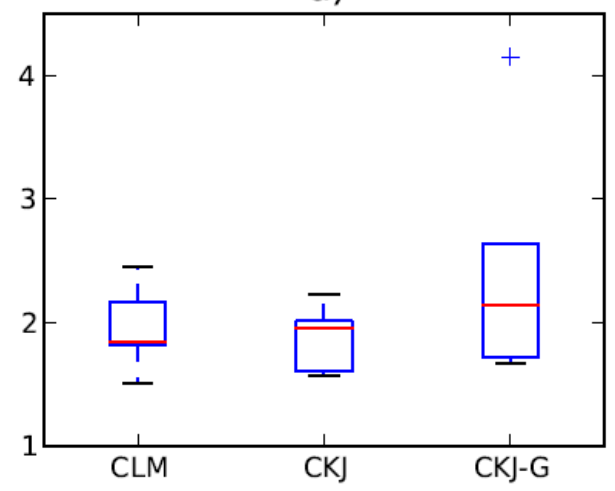

TCD

7, 4703-4740, 2013

Simulating the role of gravel on the dynamics of permafrost

S. Yi et al.

Title Page
Abstract

Conclusions

Tables

14

4

Back
Introduction

References

Figures

$>1$

\section{Close}

Fig. 7. The active layer thicknesses $(\mathrm{m})$ simulated using the three sets of schemes (a) CLM; (b) CKJ; and (c) CKJ-G schemes (see Table 1) with three soil profiles (P1: $50 \mathrm{~cm}$ sand (with gravel); P2: $130 \mathrm{~cm}$ sand (with gravel); and P3: $210 \mathrm{~cm}$ sand (with gravel)) and three slopes (S0: $0^{\circ}$; S5: $5^{\circ}$ and S10: $10^{\circ}$ ); (d) shows the statistics of the active layer thicknesses simulated using each set of schemes (red line: average; blue box: the $25 \%$ percentile; black line: $75 \%$ percentile; blue cross: outlier).

\section{Full Screen / Esc}

Printer-friendly Version

Interactive Discussion 
a) CLM

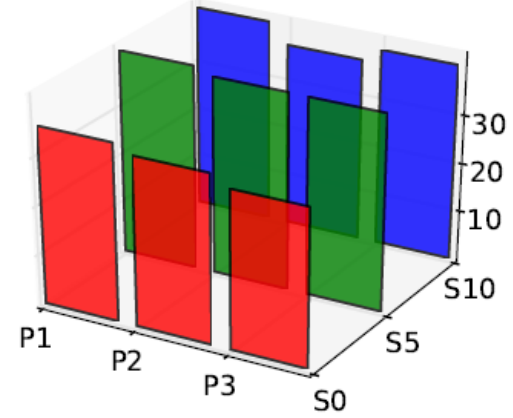

b) $\mathrm{CKJ}$

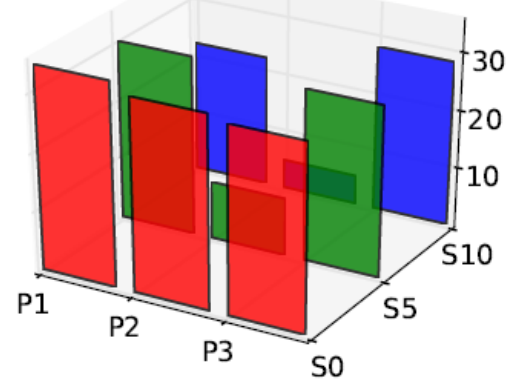

d)

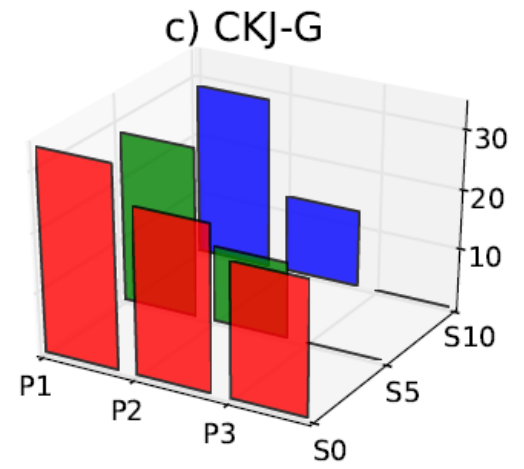

TCD

7, 4703-4740, 2013

Simulating the role of gravel on the dynamics of permafrost

S. Yi et al.

Title Page

Abstract

Introduction

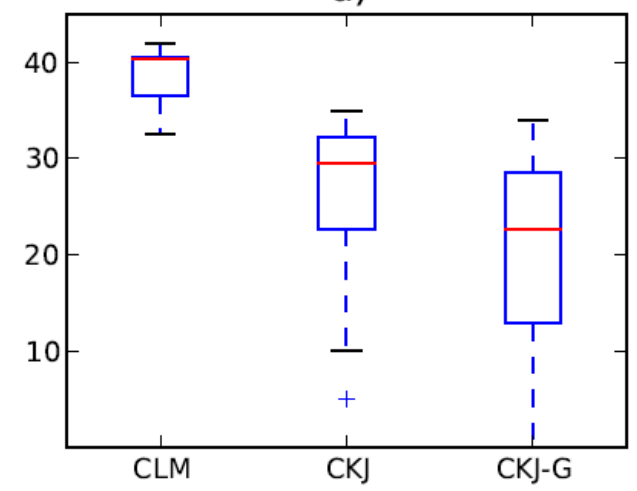

Conclusions

References

Tables

Figures

14

4

Back

Full Screen / Esc

Printer-friendly Version

Interactive Discussion 

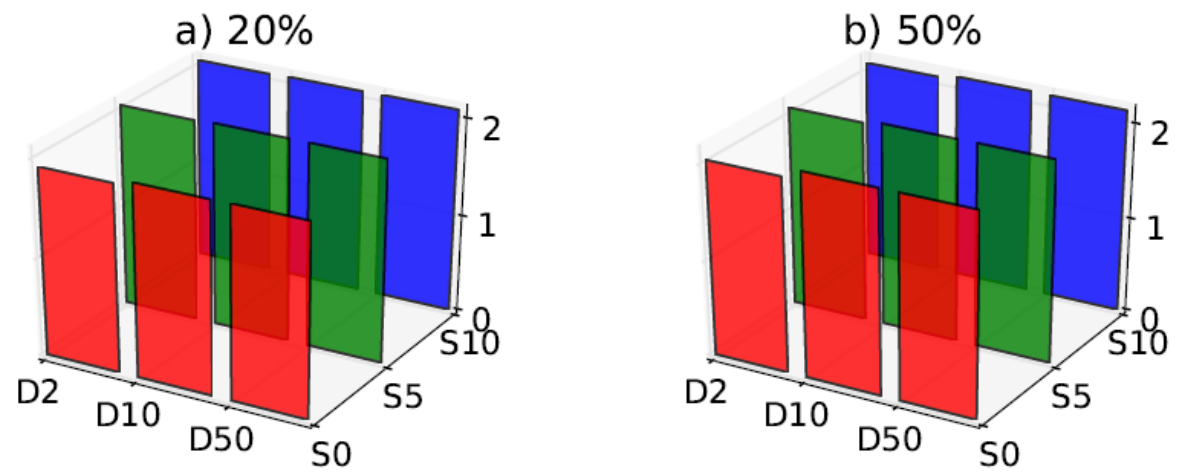

c) $80 \%$

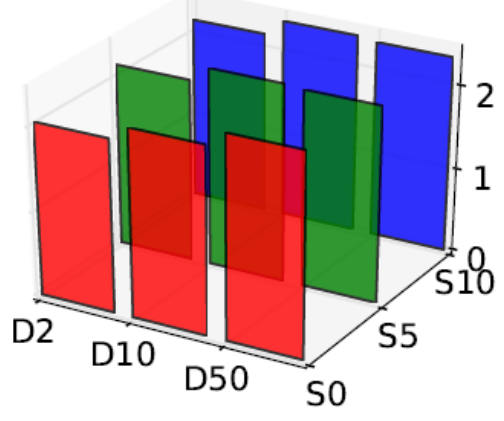

d)

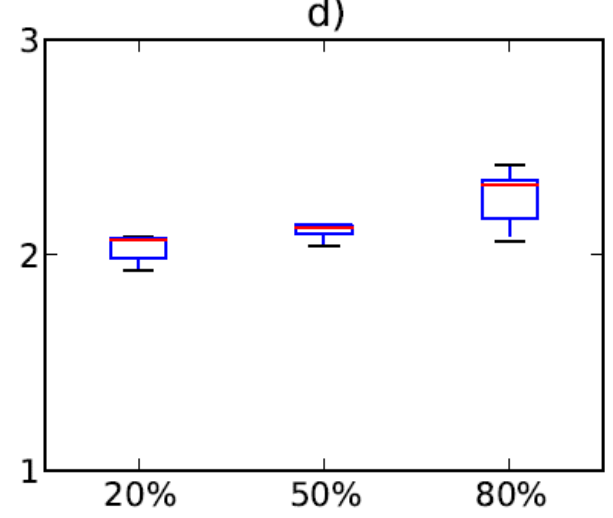

TCD

7, 4703-4740, 2013

Simulating the role of gravel on the dynamics of permafrost

S. Yi et al.

Title Page

Abstract

Conclusions

Tables

14

4

Back
Introduction

References

Figures

$>$ I

\section{Close}

Fig. 9. The active layer thicknesses $(\mathrm{m})$ simulated using the CKJ-G schemes (Table 1) with three gravel fractions and three gravel diameters (D2: $2 \mathrm{~mm}$; D10: $10 \mathrm{~mm}$; and D50: $50 \mathrm{~mm}$ ) and three slopes (S0: $0^{\circ} ; \mathrm{S} 5: 5^{\circ}$ and $\left.\mathrm{S} 10: 10^{\circ}\right)$; (d) shows the statistics of the active layer thicknesses simulated using three gravel fractions (red line: average; blue box: the $25 \%$ percentile; black line: $75 \%$ percentile; blue crosss: outlier).

Full Screen / Esc

Printer-friendly Version

Interactive Discussion 
a) $20 \%$

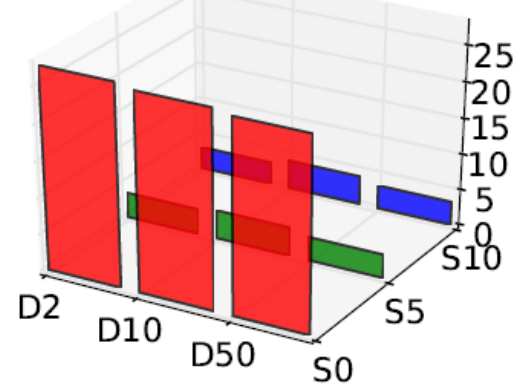

c) $80 \%$

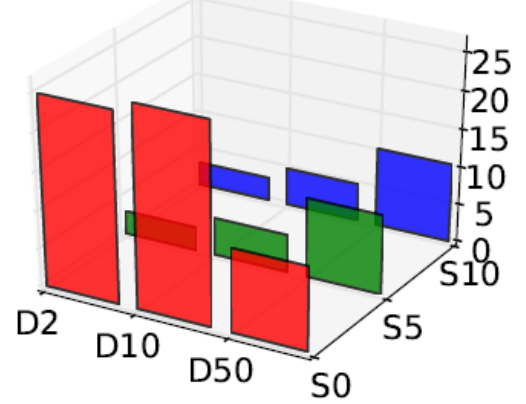

b) $50 \%$

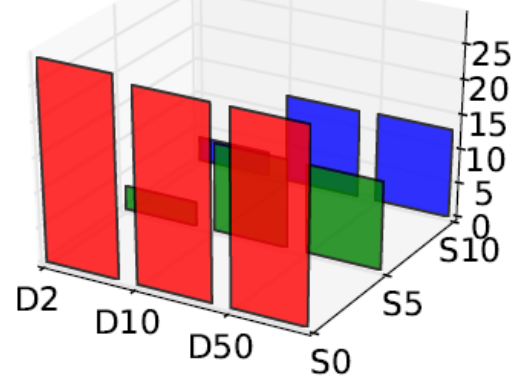

d)

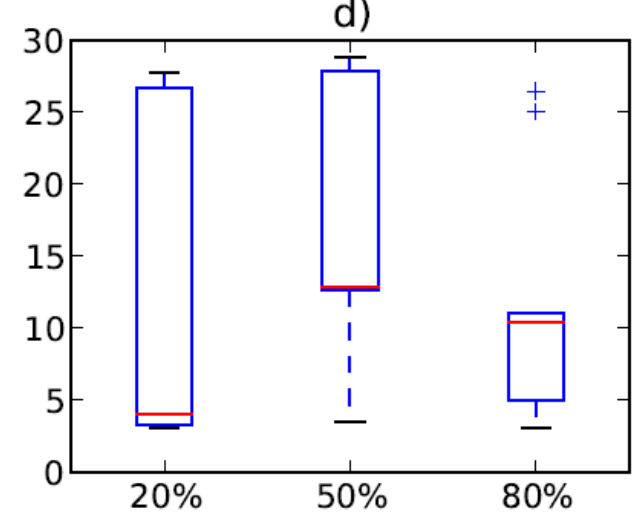

TCD

7, 4703-4740, 2013

Simulating the role of gravel on the dynamics of permafrost

S. Yi et al.

Title Page

Abstract

Introduction

Conclusions

References

Tables

Figures

14

4

Back

Full Screen / Esc

Printer-friendly Version

Interactive Discussion 


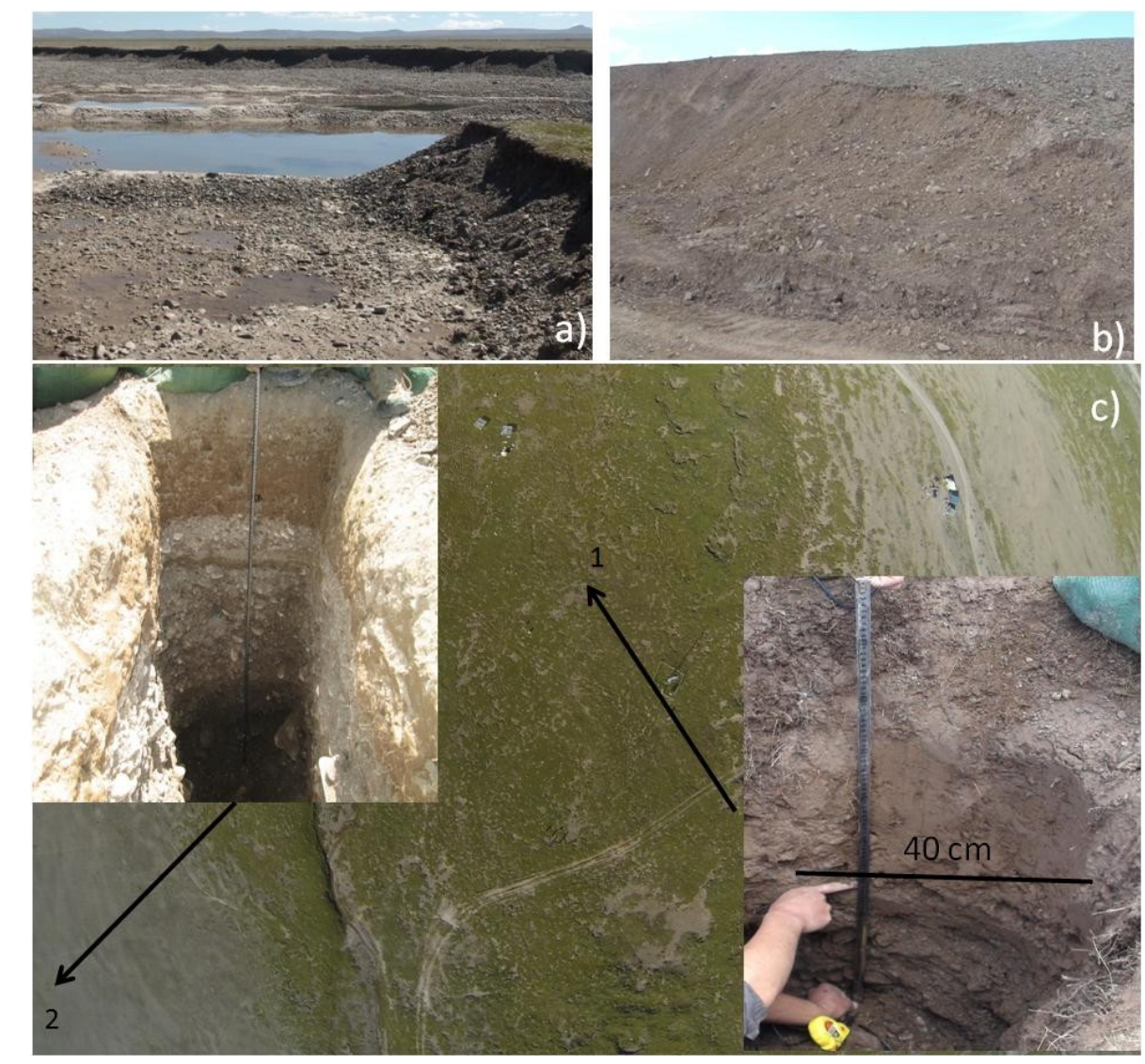

Fig. 11. Examples of gravel in soil profiles of Suli (see Fig. 1) from : (a) a $\sim 8 \mathrm{~m}$ mound; (b) a $\sim 2 \mathrm{~m}$ big pit; and (c) an alpine meadow plot (1) and a nearby tilled meadow plot (2) on a research site of Suli.

\section{TCD}

$7,4703-4740,2013$

Simulating the role of gravel on the dynamics of permafrost

S. Yi et al.

\section{Title Page}

Abstract

Conclusions

\section{Tables}

14

4

Back
Introduction

References

\section{Full Screen / Esc}

Printer-friendly Version 